\title{
Application of Proteomics to Identify Fertility Markers in Angus Bull Sperm
}

\author{
Naseer A. Kutchy ${ }^{1,2}$, Sule Dogan ${ }^{1,3}$, Xiaojun Wang ${ }^{1}$, Einko Topper ${ }^{4}$, Abdullah Kaya ${ }^{5}$, Erdogan Memili* \\ ${ }^{1}$ Department of Animal and Dairy Sciences, Mississippi State University, Mississippi State, MS, USA \\ ${ }^{2}$ Department of Genetics, Yale University, New Haven, CT, USA \\ ${ }^{3}$ IVF Michigan, Bloomfield Hills, MI, USA \\ ${ }^{4}$ Alta Genetics, Inc., Watertown, WI, USA \\ ${ }^{5}$ Department of Reproduction and Artificial Insemination, Selcuk University, Konya, Turkey
}

\section{ARTICLE INFO}

Article history:

Received December 25, 2018

Received in revised form November 15, 2019

Accepted December 20, 2019

KEYWORDS:

biomarkers,

bull fertility,

proteomics,

sperm

\begin{abstract}
The goal of the study was to ascertain sperm proteins as fertility markers in Angus bull sperm using proteomics and validating the markers through comparative sperm biology between Angus and Holstein bulls for which there are reliable fertility data available. We aimed to determine proteins differentially expressed in sperm from Angus bulls with different fertility phenotypes. Two-dimensional differential gel electrophoresis with mass-spectrometry, functional gene clusters, canonical pathways and protein networks, using integrated discovery bioinformatics software and ingenuity pathway analysis were used to identify and analyze sperm proteome. We identified 80 proteins that were differentially expressed in sperm of our experimental population. Using computational biology approaches we demonstrated involvement of structural proteins such as outer dense fiber of sperm tails 2 and enzymes including kinases, and phosphatases having functions in essential pathways in glycolysis/gluconeogenesis and free scavenging. The results are significant because analyzed proteins in Angus sperm are determinants of fertility, gene-environment interactions, as well as potential biomarkers for animal breeding.
\end{abstract}

\section{Introduction}

In addition to providing a half of the genome, sperm also transfer essential transcripts and proteins to the oocyte. Any defects in sperm proteins derived from either genome or epigenome vitally affect male fertility and early embryonic development (Dada et al. 2012). The prevalence of male infertility among the American infertile couples was found to be $17 \%$ in 2010 according to the Society for Assisted Reproductive Technology data (SART). Male infertility is also a concern in cattle reproduction as well because thousands of cows can be inseminated using cryopreserved sperm from a single bull. Since male fertility has such a paramount influence on genetic improvement of the herd, much greater considerations of male selection, their management, and replacement are needed (Rahman et al. 2017). Using high quality sperm and proper fertilization

\footnotetext{
* Corresponding Author

E-mail Address: em149@ads.msstate.edu
}

techniques are critical for maintaining the conception rates with artificial insemination (AI) in the field (Kwon et al. 2015b).

Sperm proteins can be classified by their physiological functions or their cellular locations. Locations of several sperm proteins were demonstrated to be acrosomal, mitochondrial, nuclear matrix, cytoskeletal (i.e., tubulins and actins) and membrane proteins (i.e., aquaporins). Most of the sperm proteins were structural proteins such as ODF2 and tubulin which are located in the flagellum play important roles in sperm physiology (HoyerFender et al. 1998; Donkor et al. 2004). On the other hand, some other sperm proteins such as kinases and superoxide dismutase (SOD) are synthesized in the cytosol and have enzymatic functions. Although the significance of sperm in cattle reproduction has been obvious, sperm proteins and molecular mechanisms of uncompensable infertility in Angus breed are vastly undefined. Because the bulls were similar in their genotypes, epigenetics (such as posttranslational modifications of proteins that 
influence gene expression without any changes in DNA through environmental factors such as nutrition, management, and climate) may play important roles in male fertility. Therefore, the purpose of this study was to uncover sperm proteome of Angus bulls to identify possible protein markers affecting male fertility. To accomplish our goal, we used a quantitative proteomics methods 2D-DIGE and matrix assisted laser desorption/ionization timeof-flight mass spectrometry (Choi et al. 2008) and bioinformatics. This pioneering and comprehensive proteomics study of Angus bull sperm is significant because the results are hypothesis generators and potential fertility markers to determine and measure semen quality and bull fertility.

\section{Materials and Methods}

\subsection{Experimental Design}

The frozen semen samples and the fertility data from four Angus bulls with different fertility index and satisfactory semen quality were obtained from Alta Genetics, Inc. (Watertown, WI, USA). Cryopreserved semen samples were washed three times to remove the cryoprotectants, and then the proteins were extracted for 2D-DIGE analysis. In addition, MALDITOF/TOF analysis was used to identify proteins. Further, bioinformatics and pathway analyses were carried out to identify the protein networks and pathways. All chemicals were purchased from SigmaAldrich Chemicals, St. Louis, MO, USA except those stated.

\subsection{Determination of Bull Fertility and Isolation of Sperm}

Fertility of the bulls was tested through artificial insemination(AI) of 1,265 cows on seven farms. Frozen semen samples from four bulls were distributed to seven herds, and cows were bred in standing heat. The pregnancy diagnoses were performed by rectal palpation on day 40 post insemination. The breeding numbers and the conception rates of the four bulls are presented (Figure 1). Sperm were isolated from four Angus bulls with different fertility using percoll gradient according to Feugang et al. (2009). Sperm pellets were washed with PBS (Gibco, Grand Island, NY, USA) three times, centrifuged at $500 \mathrm{~g}$ and aliquoted as $10 \times 10^{6}$ spermatozoa per tube. The pellets were kept at $-80^{\circ} \mathrm{C}$ prior to shipping, and shipped on dry ice to Appliedbiomics (Hayward, CA, USA) for 2D-DIGE and mass spectrometry. a

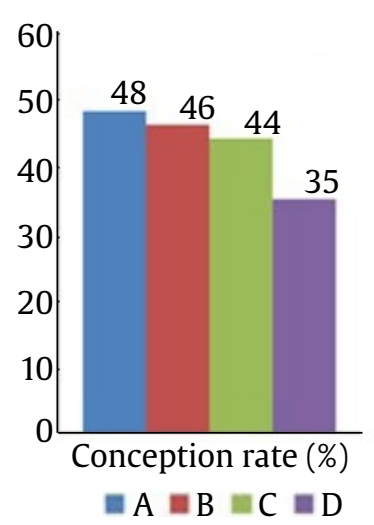

b

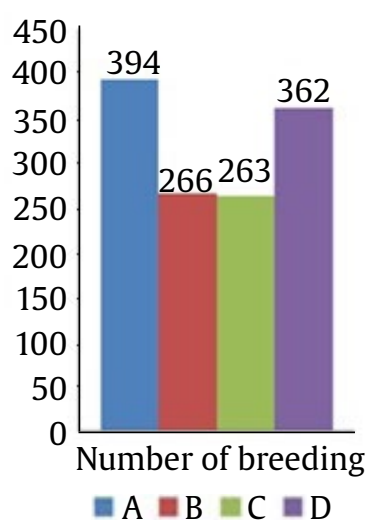

Figure 1. Fertility ranking of the bulls whose sperm were used in 2D-DIGE analysis. (a) four bulls are shown from $A$ to $D$ based on the number of breeding, (b) conception rates obtained from the field following AI for the same bulls are also displayed. Note that the fertility of these bulls gradually decreases from bull $A$ to bull D, so Bull A and Bull B were considered as higher fertility than Bull C and Bull D

\subsection{Isolation of Proteins from Sperm and CyDye Labeling}

Sperm pellets were resuspended in $120 \mu$ of $2-\mathrm{D}$ cell lysis buffer (30 mM Tris- $\mathrm{HCl}, \mathrm{pH} 8.8,7 \mathrm{M}$ urea, $2 \mathrm{M}$ thiourea, and 4\% CHAPS) supplemented with protease inhibitor cocktail (Roche San Francisco, CA, USA) followed by two seconds of sonication (VerTis, Gardiner, NY, USA). Samples were then incubated on a rotator at room temperature (RT) for 30 minutes and centrifuged at $13,000 \mathrm{~g}$ at $4^{\circ} \mathrm{C}$ for 30 minutes. The supernatant was collected, and the protein concentration was measured using Bio-Rad protein assay (Bio-Rad, Hercules, CA, USA). Proteins were labeled for each sample. Thirty micrograms of proteins were mixed with 0.7-0.9 $\mu$ l of diluted CyDye (1:5 diluted with DMF from $1 \mathrm{nmol} / \mu \mathrm{l}$ stock) and kept in the dark on ice $\left(\sim 4^{\circ} \mathrm{C}\right)$ for 30 minutes. The four samples (total concentration $20 \mu \mathrm{g} / \mathrm{gel}$ ) were mixed together to create the internal standard. Samples from each group were labeled with Cy2, Cy3, and Cy5, respectively. The labeling reaction was stopped by adding $0.7-0.9 \mu \mathrm{l}$ of $10 \mathrm{mM}$ Lysine to each sample and incubating in the dark on ice for an additional $15 \mathrm{~min}$. The labeled samples were then mixed together, and $130 \mu$ destreak solution (GE Healthcare, Piscataway Township, NJ, USA) and $100 \mu$ of Rehydration buffer (7 M urea, 2 M thiourea, 4\% CHAPS, $20 \mathrm{mg} / \mathrm{ml} \mathrm{DTT,} \mathrm{1 \%}$ Pharmalyte, and trace amount of bromophenol blue) were added to the labeling mix for a total volume of $260 \mu \mathrm{l}$. The samples were put on a rotator for $15 \mathrm{~min}$. 
and centrifuged at $16,060 \mathrm{~g}$ for another $15 \mathrm{~min}$. The labeled samples were then loaded onto a strip holder and immersed with a $13 \mathrm{~cm}$ IPG strip. Two 2D-DIGE gels were replicated for each experiment, for Bull $C$ vs. Bull A and similarly for Bull D vs. Bull B. Since the protein expression patterns from two high and two low fertility bulls were compared in the same gel, only two gels were used.

\subsection{Isoelectric Focusing (IEF) and Sodium Dodecyl Sulfate-Polyacrylamide Gel Electrophoresis (SDS- PAGE), Image Scan and Data Analysis}

Once the labeled samples were loaded, IEF (pH3-10 linear) was run according to the protocol provided by Amersham BioSciences (GE Healthcare, Piscataway Township, NJ, USA). The IPG strips were then incubated in the freshly made equilibration buffer-1 (50 mM Tris- $\mathrm{HCl}$, pH 8.8, containing $6 \mathrm{M}$ urea, $30 \%$ glycerol, $2 \%$ SDS, trace amount of bromophenol blue, and $10 \mathrm{mg} / \mathrm{ml}$ Dithiothreitol; DTT) with gentle shaking for $15 \mathrm{~min}$. Then the strips were rinsed in the fresh equilibration buffer- 2 ( $50 \mathrm{mM}$ Tris- $\mathrm{HCl}, \mathrm{pH}$ 8.8 , containing $6 \mathrm{M}$ urea, $30 \%$ glycerol, $2 \%$ SDS, trace amount of bromophenol blue, and $45 \mathrm{mg} / \mathrm{ml}$ DTT) with gentle shaking for $10 \mathrm{~min}$. Next, the IPG strips were rinsed in the SDS-gel running buffer prior to transferring into $12 \%$ SDS-gels. The SDS-gels were run at $15^{\circ} \mathrm{C}$ until the dye ran out of the gels. Gel images were scanned immediately following the SDS-PAGE using typhoon TRIO (Amersham BioSciences, GE Healthcare, Piscataway Township, NJ, USA). The scanned images were then analyzed by Image Quant software (version 6.0, Amersham BioSciences, GE Healthcare, Piscataway Township, NJ, USA), followed by in-gel analysis using DeCyder software version 6.0 (Amersham BioSciences, GE Healthcare, Piscataway Township, NJ, USA). The fold changes of the protein expression levels were obtained from in-gel DeCyder analysis.

\subsection{Identification of Differentially Expressed Proteins Using Mass Spectrometry}

Protein spots of interest were excised from preparative gels ( $600 \mu \mathrm{g}$ of protein) by using an Ettan spot picker (Amersham Biosciences, GE Healthcare, Piscataway Township, NJ, USA) and digested with trypsin (Promega, Madison, WI USA).
The trypsin-digested peptides were extracted out and de-salted using C-18 ziptip (Millipore, Billerica, MA, USA). Then, the desalted peptides were used for MALDITOF protein identification (MALDI-TOF/ TOF mass spectrophotometer, ABI-4700 from Applied Biosystems, Inc, Foster City, CA, USA). Using the Mascot search engine (Matrix Science, Boston, MA, USA), protein databases of national center for biotechnology (NCBI)/SwissProt (http://www.ncbi. nlm.nih.gov/) and (www.uniprot.org) were searched for $>95 \%$ matches of high-quality mass spectra. For the differentially expressed protein data, a ratio of protein expressions from relatively lower fertility bulls over relatively higher fertility bulls was calculated as C/A and D/B. Subsequently, an average of these two ratios was taken for each protein using the equation $[(C / A+D / B) / 2]$ to find the mean, for more accuracy. Eighty proteins were identified to be different in spermatozoa from the four bulls based on their fertility index.

\subsection{Bioinformatics and Pathway Analysis of the Differentially Expressed Proteins}

Functional gene annotation clustering of the differentially expressed proteins was performed using DAVID bioinformatics database (http://david. abcc.ncifcrf.gov) to reveal their molecular functions in biological processes. The pathway analysis was completed using ingenuity pathway, IPA (http:// www.ingenuity.com) to determine a functional interactome between the differentially expressed proteins and bull fertility. The GenInfo Identifier (GI) accession numbers of 80 proteins were imported into the IPA software prior to data analysis. Then, the unmapped proteins were determined and manually converted into their human counterparts using ENSEMBL database (http://www.ensembl.org) with their identity (\%). Afterwards, the pathway analysis was performed using IPA with the proteins that were mapped automatically and manually. The proteins that would be further analyzed using bioinformatics tolls were selected according to IPA interactome results.

\subsection{Sperm Proteins as Markers Across Breeds}

Through harnessing the power of comparative biology, we performed a comprehensive literature 
search on proteins of bovine sperm to uncover potential fertility markers that can be used in selection of breeding bulls. The proteins were included in the following groups according to their molecular physiology: Chromatin proteins, seminal plasma proteins, acrosome proteins, ATP synthesis proteins, capacitation proteins, cytoskeletal proteins, and other proteins.

\section{Results}

\subsection{Protein Analysis by 2D-DIGE}

We detected approximately 2,000 protein spots in each of the 2D gels developed using sperm from four bulls with varying fertility per gel, Bull C/Bull $A$ and Bull D/Bull B, respectively (Figure 2a and b). Among all the data obtained from the two 2D gels, 80 of the differentially expressed protein spots were detected. Overall about $4 \%$ of all protein spots were differentially expressed between relative high
( $A$ and $B$ ) and low fertility bulls (C and D), and the expression levels of these proteins ranged from -4.65 to 8.2 .

\subsection{Differentially Expressed Proteins in Sperm from Bulls with Varying Fertility}

We found total of 80 proteins that were differentially expressed in the sperm from the four bulls having varying fertility (Table 1). These expressed proteins exhibited various levels of fold differences among the bulls. While most of these proteins corresponded to known proteins, others were similar to known proteins, or to predicted proteins or hypothetical proteins.

\subsection{Bioinformatics and Pathway Analysis of the Differentially Expressed Proteins}

According to the IPA output, 47 canonical pathways and networks were identified (Table 2 and 3). Twelve of these canonical pathways were
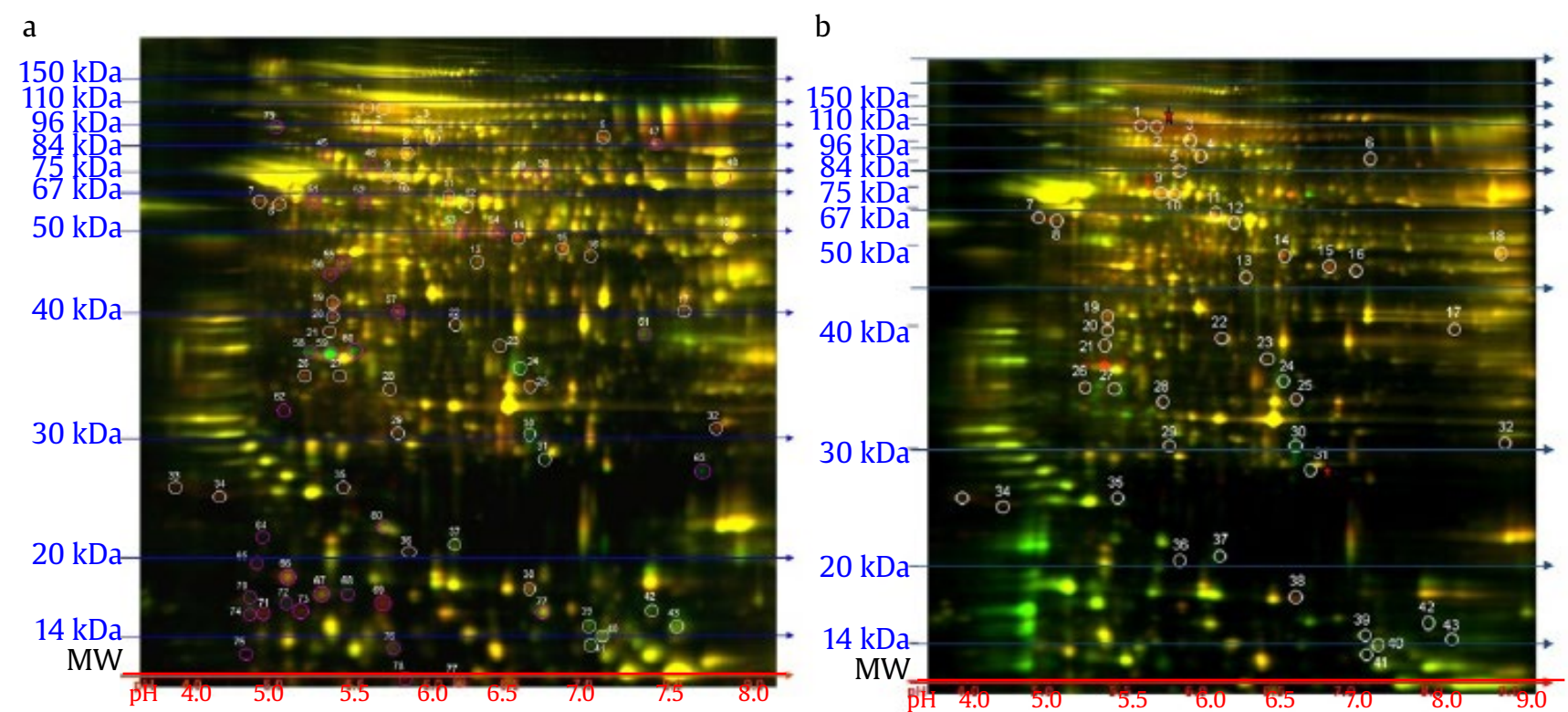

Figure 2. Differentially expressed proteins in sperm from bulls with different fertility. (a) the 2D-DIGE data obtained by using spermatozoa from (Bull C vs. Bull A). (b) 2D-DIGE data obtained by using spermatozoa from (Bull D vs. Bull B). The 2D-DIGE gel pictures analyzed by Image Quant and DeCyder software are displayed. The same amounts of protein extracts from spermatozoa were labeled separately and subjected to a $13 \mathrm{~cm}$ IPG strip (pH 3-10) and then transferred to SDS-PAGE. Differentially expressed proteins are circled; dotted circles indicate the proteins sequenced for identification. Molecular weights of markers are listed on the left, while the $\mathrm{pH}$ ranges are indicated at the bottom. Spots 2 and 31 are Outer Dense Fiber of Sperm Tails 2 (ODF2) and manganesedependent superoxide dismutase (MnSOD), (Red asterisk), respectively 
Table 1. Sperm proteins detected using 2D-DIGE analysis and LC-MSMS. Differentially expressed proteins in the spermatozoa from the four bulls with different fertility were represented. This table is composed of the spot numbers, gi accession numbers, and molecular weights of these 80 proteins

\begin{tabular}{|c|c|c|c|c|c|c|c|c|c|c|c|}
\hline $\begin{array}{l}\text { Top ranked protein } \\
\text { name (species) }\end{array}$ & $\begin{array}{l}\text { Ratio bull } \\
\text { C/bull A }\end{array}$ & $\begin{array}{l}\text { Ratio bull } \\
\text { D/bull B }\end{array}$ & $\begin{array}{l}\text { Average } \\
\text { ratio }\end{array}$ & $\begin{array}{l}\text { Accession } \\
\text { no. }\end{array}$ & $\begin{array}{l}\text { Protein } \\
\text { MW }\end{array}$ & $\begin{array}{l}\text { Protein } \\
\text { PI }\end{array}$ & $\begin{array}{l}\text { Pep. } \\
\text { count }\end{array}$ & $\begin{array}{l}\text { Protein } \\
\text { score }\end{array}$ & $\begin{array}{l}\text { Protein } \\
\text { score } \\
\text { C. I. \% } \\
\end{array}$ & $\begin{array}{l}\text { Total } \\
\text { ion } \\
\text { score }\end{array}$ & $\begin{array}{l}\text { Total } \\
\text { ion } \\
\text { C. I. \% }\end{array}$ \\
\hline $\begin{array}{l}\text { PREDICTED: } \\
\text { similar to testis } \\
\text { specific } 10 \\
\text { isoform } 1 \text { [Bos } \\
\text { taurus] }\end{array}$ & 1.71 & 8.95 & 5.33 & gi|194671321 & 81188 & 5.65 & 13 & 164 & 100 & 63 & 99.8 \\
\hline $\begin{array}{c}\text { Outer dense fiber } \\
\text { of sperm tails } 2 \\
\text { [Bos taurus] }\end{array}$ & 1.64 & 14.8 & 8.21 & gi|84000345 & 75450.6 & 7.52 & 13 & 235 & 100 & 166 & 100 \\
\hline $\begin{array}{l}\text { PREDICTED: } \\
\text { similar to EF- } \\
\text { hand domain } \\
\text { (C-terminal) } \\
\text { containing } 1 \\
\text { isoform 1 [Bos } \\
\text { taurus] }\end{array}$ & 1.11 & 1.37 & 1.24 & gi|76650703 & 73984.5 & 5.78 & 26 & 473 & 100 & 272 & 100 \\
\hline $\begin{array}{c}\text { Outer dense fiber } \\
\text { of sperm tails } 2 \\
\text { [Bos taurus] }\end{array}$ & 1.46 & 1.56 & 1.51 & gi|84000345 & 75450.6 & 7.52 & 27 & 554 & 100 & 397 & 100 \\
\hline $\begin{array}{c}\text { Outer dense fiber } \\
\text { of sperm tails } 2 \\
\text { [Bos taurus] }\end{array}$ & 1.62 & 1.49 & 1.55 & gi|84000345 & 75450.6 & 7.52 & 29 & 697 & 100 & 514 & 100 \\
\hline $\begin{array}{l}\text { Chain E, leech- } \\
\text { derived tryptase } \\
\text { inhibitorTRYPSIN } \\
\text { COMPLEX }\end{array}$ & 2.03 & 2.07 & 2.05 & gi|3318722 & 23457.4 & 8.26 & 2 & 73 & 96.6 & 56 & 98.9 \\
\hline $\begin{array}{l}\text { Tubulin, beta 2C } \\
\text { [homo sapiens] }\end{array}$ & 1.89 & 1.86 & 1.87 & gi|23958133 & 49808 & 4.83 & 20 & 543 & 100 & 324 & 100 \\
\hline $\begin{array}{l}\text { Tubulin, beta, } 2 \\
\text { [homo sapiens] }\end{array}$ & 2.09 & 1.93 & 2.01 & gi|5174735 & 49799 & 4.79 & 22 & 585 & 100 & 330 & 100 \\
\hline $\begin{array}{l}\text { PREDICTED: } \\
\text { similar to outer } \\
\text { dense fiber of } \\
\text { sperm tails } 2 \\
\text { isoform } 10 \text { [canis } \\
\text { familiaris] }\end{array}$ & 1.18 & 1.42 & 1.3 & gi|73967892 & 52075.9 & 5.81 & 26 & 536 & 100 & 348 & 100 \\
\hline $\begin{array}{l}\text { PREDICTED: } \\
\text { similar to outer } \\
\text { dense fiber of } \\
\text { sperm tails } 2 \\
\text { isoform } 10 \text { [canis } \\
\text { familiaris] }\end{array}$ & 1.3 & 1.62 & 1.46 & gi|73967892 & 52075.9 & 5.81 & 23 & 604 & 100 & 434 & 100 \\
\hline $\begin{array}{l}\text { Tubulin, alpha 1a } \\
\text { [mus musculus] }\end{array}$ & 2.79 & 1.51 & 2.15 & gi|6678465 & 49927.6 & 4.97 & 15 & 688 & 100 & 520 & 100 \\
\hline $\begin{array}{l}\text { Enolase } 1 \text { [Bos } \\
\text { taurus] }\end{array}$ & 1.03 & -1.3 & -0.35 & gi|87196501 & 47296.4 & 6.37 & 21 & 666 & 100 & 458 & 100 \\
\hline $\begin{array}{l}\text { Hypothetical } \\
\text { protein } \\
\text { LOC511761 [bos } \\
\text { taurus] }\end{array}$ & 1.69 & 1.49 & 1.59 & gi|115495817 & 30193.3 & 6.21 & 15 & 427 & 100 & 279 & 100 \\
\hline $\begin{array}{l}\text { PREDICTED: } \\
\text { similar to tubulin } \\
\text { alpha-3 chain } \\
\text { (alpha-tubulin 3) } \\
\text { [canis familiaris] }\end{array}$ & 3.2 & 1.83 & 2.51 & gi|73996007 & 49913.6 & 4.97 & 15 & 577 & 100 & 418 & 100 \\
\hline $\begin{array}{l}\text { Tubulin, alpha 1a } \\
\text { [mus musculus] }\end{array}$ & 1.97 & 2.53 & 2.25 & gi|6678465 & 49927.6 & 4.97 & 14 & 442 & 100 & 314 & 100 \\
\hline
\end{tabular}


Table 1. Continued

\begin{tabular}{|c|c|c|c|c|c|c|c|c|c|c|c|}
\hline $\begin{array}{l}\text { Top ranked protein } \\
\text { name (species) }\end{array}$ & $\begin{array}{l}\text { Ratio bull } \\
\text { C/bull A }\end{array}$ & $\begin{array}{l}\text { Ratio bull } \\
\text { D/bull B }\end{array}$ & $\begin{array}{l}\text { Average } \\
\text { ratio }\end{array}$ & $\begin{array}{l}\text { Accession } \\
\text { no. }\end{array}$ & $\begin{array}{l}\text { Protein } \\
\text { MW }\end{array}$ & $\begin{array}{l}\text { Protein } \\
\text { PI }\end{array}$ & $\begin{array}{l}\text { Pep. } \\
\text { count }\end{array}$ & $\begin{array}{l}\text { Protein } \\
\text { score }\end{array}$ & $\begin{array}{l}\text { Protein } \\
\text { score } \\
\text { C. I. } \%\end{array}$ & $\begin{array}{l}\text { Total } \\
\text { ion } \\
\text { score }\end{array}$ & $\begin{array}{l}\text { Total } \\
\text { ion } \\
\text { C. I. \% }\end{array}$ \\
\hline $\begin{array}{l}\text { short-chain } \\
\text { acyl-CoA } \\
\text { dehydrogenase } \\
\text { [bos taurus] }\end{array}$ & 1.68 & 1.96 & 1.82 & gi|777735757 & 44523.9 & 8.82 & 15 & 352 & 100 & 220 & 100 \\
\hline $\begin{array}{l}\text { Lactate } \\
\text { dehydrogenase } \\
\text { a-like 6B [bos } \\
\text { taurus] }\end{array}$ & 2.25 & 1.41 & 1.83 & gi|78369344 & 41565.8 & 8.91 & 17 & 646 & 100 & 483 & 100 \\
\hline $\begin{array}{l}\text { Phosphoglycerate } \\
\text { kinase } 2 \text { [bos } \\
\text { taurus] }\end{array}$ & 1.64 & 1.68 & 1.66 & gi|174840786 & 44729.3 & 8.51 & 19 & 482 & 100 & 332 & 100 \\
\hline $\begin{array}{l}\text { mCG20287 [mus } \\
\text { musculus] }\end{array}$ & 2.63 & 1.98 & 2.3 & gi|148676266 & 39342.1 & 5.14 & 13 & 435 & 100 & 261 & 100 \\
\hline $\begin{array}{l}\text { mCG20287 [Mus } \\
\text { musculus] }\end{array}$ & 2.71 & 2.3 & 2.5 & gi|148676266 & 39342.1 & 5.14 & 11 & 376 & 100 & 231 & 100 \\
\hline $\begin{array}{l}\text { TUBB2C protein } \\
\text { [homo sapiens] }\end{array}$ & 3.8 & 1.9 & 2.85 & gi|14124960 & 25858.4 & 4.95 & 13 & 299 & 100 & 147 & 100 \\
\hline $\begin{array}{l}\text { hCG1992406, } \\
\text { isoform CRA_b } \\
\text { [homo sapiens] }\end{array}$ & 3.29 & 2.29 & 2.79 & gi|119576011 & 42187 & 5.03 & 8 & 265 & 100 & 194 & 100 \\
\hline $\begin{array}{l}\text { Chain D, } \\
\text { cytochrome Bc1 } \\
\text { complex from } \\
\text { bovine }\end{array}$ & 1.64 & 1.48 & 1.56 & gi|4139395 & 27269.5 & 6.49 & 13 & 301 & 100 & 179 & 100 \\
\hline $\begin{array}{l}\text { Hypothetical } \\
\text { protein } \\
\text { LOC510569 [bos } \\
\text { taurus] }\end{array}$ & -2.93 & -2.41 & -2.67 & gi|156120505 & 17804.6 & 5.94 & 4 & 77 & 98.5 & 39 & 45.3 \\
\hline $\begin{array}{l}\text { Hypothetical } \\
\text { protein TP0959 } \\
\text { [treponema } \\
\text { pallidum }\end{array}$ & 2.03 & 1.82 & 1.92 & gi|15639943 & 13894 & 8.89 & 7 & 74 & 64.7 & & \\
\hline $\begin{array}{l}\text { PREDICTED: } \\
\text { similar to } \\
\text { ENSANGP00 } \\
\text { 000002667 } \\
\text { [bos taurus] }\end{array}$ & 3.01 & 1.77 & 2.39 & gi|194674718 & 19864.8 & 5.62 & 5 & 310 & 100 & 253 & 100 \\
\hline $\begin{array}{l}\text { mCG20287 [mus } \\
\text { musculus] }\end{array}$ & 2.35 & 1.52 & 1.93 & gi|148676266 & 39342.1 & 5.14 & 14 & 426 & 100 & 310 & 100 \\
\hline $\begin{array}{l}\text { Unnamed protein } \\
\text { product [mus } \\
\text { musculus] }\end{array}$ & 2.56 & 2.45 & 2.5 & gi|26355849 & 32237.9 & 5.56 & 9 & 323 & 100 & 223 & 100 \\
\hline $\begin{array}{l}\text { Phosphatidyletha } \\
\text { nolamine- } \\
\text { binding protein } \\
4 \text { [bos taurus] }\end{array}$ & 3.15 & 1.32 & 2.23 & gi|77735827 & 25129.6 & 5.87 & 4 & 60 & 35.7 & 23 & 0 \\
\hline $\begin{array}{l}\text { hypothetical } \\
\text { protein } \\
\text { LOC510569 } \\
\text { [bos taurus] }\end{array}$ & -3.19 & -2.92 & -3.05 & gi|156120505 & 17804.6 & 5.94 & 6 & 309 & 100 & 234 & 100 \\
\hline $\begin{array}{l}\text { Manganous } \\
\text { superoxide } \\
\text { dismutase; } \\
\text { MnSOD [bos } \\
\text { taurus] }\end{array}$ & -2.91 & -6.4 & -4.65 & gi|7555818 & 24574.6 & 8.7 & 6 & 313 & 100 & 254 & 100 \\
\hline $\begin{array}{l}\text { PREDICTED: } \\
\text { hypothetical } \\
\text { protein LOC736 } \\
248 \text { isoform } 2 \\
\text { [pan troglodytes] }\end{array}$ & 4.37 & 4.23 & 4.3 & gi|114585016 & 43100.4 & 5.07 & 10 & 460 & 100 & 342 & 100 \\
\hline $\begin{array}{l}\text { TUBB2C protein } \\
\text { [homo sapiens] }\end{array}$ & 2.13 & 1.86 & 1.99 & gi|14124960 & 25858.4 & 4.95 & 13 & 473 & 100 & 303 & 100 \\
\hline
\end{tabular}


Table 1. Continued

\begin{tabular}{|c|c|c|c|c|c|c|c|c|c|c|}
\hline $\begin{array}{l}\text { Top ranked protein } \\
\text { name (species) }\end{array}$ & $\begin{array}{l}\text { Ratio bull } \\
\text { C/bull A }\end{array}$ & $\begin{array}{l}\text { Ratio bull } \\
\text { D/bull B }\end{array}$ & $\begin{array}{ll}\text { Average } & \text { Accession } \\
\text { ratio } & \text { no. }\end{array}$ & $\begin{array}{l}\text { Protein } \\
\text { MW }\end{array}$ & $\begin{array}{l}\text { Protein } \\
\text { PI }\end{array}$ & $\begin{array}{l}\text { Pep. } \\
\text { count }\end{array}$ & $\begin{array}{l}\text { Protein } \\
\text { score }\end{array}$ & $\begin{array}{l}\text { Protein } \\
\text { score } \\
\text { C. I. \% }\end{array}$ & $\begin{array}{l}\text { Total } \\
\text { ion } \\
\text { score }\end{array}$ & $\begin{array}{l}\text { Total } \\
\text { ion } \\
\text { C. I. \% }\end{array}$ \\
\hline $\begin{array}{l}\text { TUBB2C protein } \\
\text { [homo sapiens] }\end{array}$ & 2.2 & 2.29 & 2.24 gi|14124960 & 25858.4 & 4.95 & 10 & 258 & 100 & 140 & 100 \\
\hline $\begin{array}{l}\text { PREDICTED: } \\
\text { similar to } \\
\text { ENSANG }\end{array}$ & 2.08 & 1.35 & 1.71 gi|194674718 & 19864.8 & 5.62 & 6 & 276 & 100 & 212 & 100 \\
\hline $\begin{array}{l}\text { P00000002667 } \\
\text { [bos taurus] }\end{array}$ & 2.18 & 1.52 & 1.85 gi|194674718 & 19864.8 & 5.62 & 6 & 286 & 100 & 222 & 100 \\
\hline $\begin{array}{l}\text { PREDICTED: } \\
\text { similar to } \\
\text { ENSANG } \\
\text { P00000002667 } \\
\text { [bos taurus] }\end{array}$ & -1.91 & -1.97 & -1.94 gi|148744160 & 18156.9 & 6.71 & 12 & 282 & 100 & 142 & 100 \\
\hline $\begin{array}{l}\text { ACP1 protein } \\
\text { [bos taurus] } \\
\text { heat shock } \\
\text { protein, alpha- } \\
\text { crystallin-related, } \\
\text { B9 [bos taurus] }\end{array}$ & 1.94 & 2.15 & 2.04 gi|94966950 & 16773.2 & 8.22 & 8 & 476 & 100 & 355 & 100 \\
\hline $\begin{array}{l}\text { PREDICTED: } \\
\text { similar to } \\
\text { Acrosomal } \\
\text { protein SP-10 } \\
\text { precursor } \\
\text { (acrosomal } \\
\text { vesicle protein-1) } \\
\text { isoform 3 [Ca }\end{array}$ & -1.67 & -1.32 & -1.49 gi|73954519 & 26598.9 & 5.08 & 6 & 101 & 100 & 53 & 99.2 \\
\hline $\begin{array}{l}\text { acrosomal vesicle } \\
\text { protein } 1 \text { [bos } \\
\text { taurus] }\end{array}$ & 1.24 & -1.63 & -0.19 gi|115495399 & 28934.4 & 4.53 & 7 & 113 & 100 & 55 & 99.6 \\
\hline $\begin{array}{l}\text { Alpha enolase [bos } \\
\text { taurus] }\end{array}$ & -1.4 & -1.37 & -1.38 gi|4927286 & 47247.3 & 6.44 & 8 & 154 & 100 & 105 & 100 \\
\hline $\begin{array}{l}\text { Chain } \mathrm{B} \text {, refined } \\
1.8 \text { angstroms } \\
\text { aesolution crystal } \\
\text { structure Of } \\
\text { porcine epsilon- } \\
\text { trypsin }\end{array}$ & -2.07 & -2.09 & -2.08 gi|999627 & 8813.5 & 6.67 & 2 & 119 & 100 & 96 & 100 \\
\hline $\begin{array}{l}\text { Chain B, refined } \\
1.8 \text { angstroms } \\
\text { resolution crystal } \\
\text { structure Of } \\
\text { porcine epsilon- } \\
\text { trypsin }\end{array}$ & -2.14 & -2.88 & -2.51 gi|999627 & 8813.5 & 6.67 & 2 & 104 & 100 & 79 & 100 \\
\hline $\begin{array}{l}\text { Outer dense fiber } \\
\text { of sperm tails } 2 \\
\text { [bos taurus] }\end{array}$ & 1.07 & 1.46 & 1.26 gi|84000345 & 75450.6 & 7.52 & 20 & 373 & 100 & 282 & 100 \\
\hline $\begin{array}{l}\text { PREDICTED: } \\
\text { heat shock } \\
\text { 60kDa protein } \\
1 \text { (chaperonin) } \\
\text { [bos taurus] }\end{array}$ & 1.13 & 1.06 & 1.09 gi|119888228 & 74984.7 & 9.05 & 23 & 1,060 & 100 & 865 & 100 \\
\hline $\begin{array}{l}\text { plasma glutamate } \\
\text { carboxypeptidase } \\
\text { precursor [bos } \\
\text { taurus] }\end{array}$ & 1.07 & 2.41 & 1.74 gi|115495837 & 51646.3 & 5.55 & 11 & 453 & 100 & 389 & 100 \\
\hline $\begin{array}{l}\text { Chain A, the } \\
\text { refined three- } \\
\text { dimensional } \\
\text { structure of cat } \\
\text { muscle (M1) } \\
\text { pyruvate kinase, } \\
\text { at a resolutio } \\
\end{array}$ & 1.6 & 2.37 & 1.98 gi|157833510 & 57877.9 & 7.23 & 19 & 178 & 100 & 64 & 99.9 \\
\hline
\end{tabular}


Table 1. Continued

\begin{tabular}{|c|c|c|c|c|c|c|c|c|c|c|c|}
\hline $\begin{array}{l}\text { Top ranked protein } \\
\text { name (species) }\end{array}$ & $\begin{array}{l}\text { Ratio bull } \\
\text { C/bull A }\end{array}$ & $\begin{array}{l}\text { Ratio bull } \\
\text { D/bull B }\end{array}$ & $\begin{array}{l}\text { Average } \\
\text { ratio }\end{array}$ & $\begin{array}{l}\text { Accession } \\
\text { no. }\end{array}$ & $\begin{array}{l}\text { Protein } \mathrm{P} \\
\text { MW } \mathrm{P}\end{array}$ & $\begin{array}{l}\text { Protein } \\
\text { PI }\end{array}$ & $\begin{array}{l}\text { Pep. } \\
\text { count }\end{array}$ & $\begin{array}{l}\text { Protein } \\
\text { score }\end{array}$ & $\begin{array}{l}\text { Protein } \\
\text { score } \\
\text { C. I. \% }\end{array}$ & $\begin{array}{l}\text { Total } \\
\text { ion } \\
\text { score } \\
\end{array}$ & $\begin{array}{l}\text { Total } \\
\text { ion } \\
\text { C. I. \% } \\
\end{array}$ \\
\hline $\begin{array}{l}\text { Glyceraldehyde- } \\
\text { 3-phosphate } \\
\text { dehydrogenase, } \\
\text { spermatogenic } \\
\text { [bos taurus] }\end{array}$ & 1.1 & 1.89 & 1.49 & gi|110626121 & 43260.3 & 8.32 & 19 & 596 & 100 & 422 & 100 \\
\hline $\begin{array}{l}\text { Tektin } 3 \\
\text { [bos taurus] }\end{array}$ & 1.04 & 2.73 & 1.88 & gi|149773556 & 56645.5 & 6.42 & 28 & 661 & 100 & 414 & 100 \\
\hline $\begin{array}{l}\text { Tektin } 3 \\
\text { [bos taurus] }\end{array}$ & 1.04 & -4.64 & -1.8 & gi|149773556 & 56645.5 & 6.42 & 26 & 571 & 100 & 363 & 100 \\
\hline $\begin{array}{l}\text { Tubulin, alpha 1a } \\
\text { [mus musculus] }\end{array}$ & 2.5 & 2.51 & 2.5 & gi|6678465 & 49927.6 & 4.97 & 14 & 452 & 100 & 317 & 100 \\
\hline $\begin{array}{l}\text { Chain A, } \\
\text { cytochrome Bc1 } \\
\text { complex from } \\
\text { bovine }\end{array}$ & 1.29 & 2.46 & 1.87 & gi|4139392 & 49181.3 & 5.46 & 25 & 845 & 100 & 588 & 100 \\
\hline $\begin{array}{l}\text { 5'-nucleotidase, } \\
\text { cytosolic IB [bos } \\
\text { taurus] }\end{array}$ & 1.42 & 1.35 & 1.38 & gi|84370143 & 63970.7 & 8.8 & 20 & 416 & 100 & 261 & 100 \\
\hline $\begin{array}{l}\text { actin-like 7A [bos } \\
\text { taurus] }\end{array}$ & 1.88 & -1.25 & 0.31 & gi|84370183 & 48984.7 & 6.29 & 21 & 610 & 100 & 427 & 100 \\
\hline $\begin{array}{l}\text { PREDICTED: } \\
\text { similar to actin- } \\
\text { related protein } \\
\text { T1 (ARP-T1) [bos } \\
\text { taurus] }\end{array}$ & 1.56 & 1.91 & 1.73 & gi|61878077 & 42103.3 & 5.39 & 14 & 306 & 100 & 202 & 100 \\
\hline $\begin{array}{l}\text { actin-related } \\
\text { protein T2 [bos } \\
\text { taurus] }\end{array}$ & 2.35 & -1.11 & 0.62 & gi|84000199 & 41886.4 & 5.48 & 20 & 470 & 100 & 281 & 100 \\
\hline $\begin{array}{l}\text { WBP2 N-terminal } \\
\text { like [bos taurus] }\end{array}$ & 2.22 & -1.64 & 0.29 & gi|126723634 & 31945.6 & 5.61 & 6 & 288 & 100 & 248 & 100 \\
\hline $\begin{array}{l}\text { PREDICTED: } \\
\text { similar to sp32 } \\
\text { [bos taurus] }\end{array}$ & -7.14 & 3.07 & -2.03 & gi|194666681 & 61196.7 & 5.11 & 9 & 362 & 100 & 301 & 100 \\
\hline $\begin{array}{l}\text { PREDICTED: } \\
\text { similar to sp32 } \\
\text { [bos taurus] }\end{array}$ & -14.1 & 7.21 & -3.44 & gi|194666681 & 61196.7 & 5.11 & 9 & 422 & 100 & 354 & 100 \\
\hline $\begin{array}{l}\text { PREDICTED: } \\
\text { similar to sp32 } \\
\text { [bos taurus] }\end{array}$ & -4.52 & 2.73 & -0.89 & gi|194666681 & 61196.7 & 5.11 & 11 & 509 & 100 & 454 & 100 \\
\hline $\begin{array}{l}\text { PREDICTED: } \\
\text { similar to } \\
\text { voltage- } \\
\text { dependent anion } \\
\text { channel } 2 \text { [equus } \\
\text { caballus] }\end{array}$ & -2.33 & -1.07 & -1.7 & gi|149689995 & 31524.5 & 7.46 & 6 & 96 & 100 & 63 & 99.9 \\
\hline $\begin{array}{l}\text { Tyrosine } \\
\text { 3-monoox } \\
\text { ygenase/ } \\
\text { tryptophan } \\
\text { 5-monooxy }\end{array}$ & 3.7 & 1.3 & 2.5 & gi|68085578 & 27695.8 & 4.73 & 8 & 130 & 100 & 40 & 65.6 \\
\hline $\begin{array}{l}\text { genase activation } \\
\text { protein, zeta } \\
\text { polypeptide } \\
\text { [homo sapi } \\
\text { 3-oxoacid CoA } \\
\text { transferase } 2 \text { [bos } \\
\text { taurus] }\end{array}$ & -56.7 & 1.1 & -27.8 & gi|148223655 & 55973.1 & 7.15 & 3 & 76 & 98.4 & 45 & 75.5 \\
\hline $\begin{array}{l}\text { PREDICTED: } \\
\text { similar to leucine } \\
\text { rich repeat } \\
\text { containing 37A } \\
\text { [bos taurus] }\end{array}$ & 1.27 & -6.7 & -2.71 & gi|194676234 & 280818.2 & 4.87 & 5 & 102 & 100 & 91 & 100 \\
\hline
\end{tabular}


Table 1. Continued

\begin{tabular}{|c|c|c|c|c|c|c|c|c|c|c|c|}
\hline $\begin{array}{l}\text { Top ranked protein } \\
\text { name (species) }\end{array}$ & $\begin{array}{l}\text { Ratio bull } \\
\text { C/bull A }\end{array}$ & $\begin{array}{l}\text { Ratio bull } \\
\text { D/bull B }\end{array}$ & $\begin{array}{l}\text { Average } \\
\text { ratio }\end{array}$ & $\begin{array}{l}\text { Accession } \\
\text { no. }\end{array}$ & $\begin{array}{l}\text { Protein } \\
\text { MW }\end{array}$ & $\begin{array}{l}\text { Protein } \\
\text { PI }\end{array}$ & $\begin{array}{l}\text { Pep. } \\
\text { count }\end{array}$ & $\begin{array}{l}\text { Protein } \\
\text { score }\end{array}$ & $\begin{array}{l}\text { Protein } \\
\text { score } \\
\text { C. I. \% }\end{array}$ & $\begin{array}{l}\text { Total } \\
\text { ion } \\
\text { score }\end{array}$ & $\begin{array}{l}\text { Total } \\
\text { ion } \\
\text { C. I. \% }\end{array}$ \\
\hline $\begin{array}{l}\text { Chain A, } \\
\text { 12-Bromodo } \\
\text { decanoic acid } \\
\text { binds Inside } \\
\text { the Calyx of } \\
\text { bovine beta- } \\
\text { lactoglobulin }\end{array}$ & 1.85 & -4.32 & $-1.23 \xi$ & gi|6980895 & 18355.4 & 4.76 & 12 & 612 & 100 & 463 & 100 \\
\hline $\begin{array}{l}\text { Seminal vesicle } \\
\text { secretory } \\
\text { protein } 109 \\
\text { [bos taurus] }\end{array}$ & 1.55 & -3.42 & $-0.93 \xi$ & gi|47564036 & 15470.2 & 4.91 & 8 & 557 & 100 & 457 & 100 \\
\hline $\begin{array}{l}\text { Chain A, bull } \\
\text { seminal plasma } \\
\text { Pdc-109 } \\
\text { fibronectin } \\
\text { type Ii module }\end{array}$ & 1.34 & -2.87 & $-0.76 \xi$ & gi|20663779 & 12787.8 & 5.08 & 9 & 610 & 100 & 516 & 100 \\
\hline $\begin{array}{l}\text { Phosphodi } \\
\text { esterase 6D, } \\
\text { cGMP-specific, } \\
\text { rod, delta [bos } \\
\text { taurus] }\end{array}$ & -1.6 & -1.95 & $-1.77 \varepsilon$ & gi|27806061 & 17378.8 & 5.57 & 4 & 223 & 100 & 197 & 100 \\
\hline $\begin{array}{l}\text { Sperm } \\
\text { acrosome } \\
\text { associated } 3 \\
\text { [bos taurus] }\end{array}$ & 3.37 & -1.1 & 1.13 & gi|157279923 & 18086.8 & 5.87 & 2 & 127 & 100 & 107 & 100 \\
\hline $\begin{array}{l}\text { PREDICTED: } \\
\text { similar to } \\
\text { Thioredoxin } \\
\text { domain- } \\
\text { containing } \\
\text { protein } 5 \\
\text { precursor } \\
\text { (thioredoxin-l } \\
\text { ike protein p }\end{array}$ & -1.23 & -7.94 & $-4.58 \xi$ & gi|194223000 & 39011.2 & 5.56 & 6 & 50 & 0 & & \\
\hline $\begin{array}{l}\text { seminal vesicle } \\
\text { secretion } 8 \\
\text { [bos taurus] }\end{array}$ & 3.03 & -2.32 & 0.35 & gi|28849949 & 16129.7 & 4.9 & 6 & 175 & 100 & 117 & 100 \\
\hline $\begin{array}{l}\text { PREDICTED: } \\
\text { similar to sp32 } \\
\text { [bos taurus] }\end{array}$ & -3.18 & -1.1 & -2.14 & gi|194666681 & 61196.7 & 5.11 & 2 & 142 & 100 & 131 & 100 \\
\hline $\begin{array}{l}\text { PREDICTED: } \\
\text { similar to sp32 } \\
\text { [bos taurus] }\end{array}$ & 2.63 & -1.49 & 0.57 & gi|194666681 & 61196.7 & 5.11 & 4 & 95 & 100 & 81 & 100 \\
\hline $\begin{array}{l}\text { PREDICTED: } \\
\text { similar to } \\
\text { thioredoxin } \\
\text { domain- } \\
\text { containing } \\
\text { protein } 5 \\
\text { precursor } \\
\text { (thioredoxin- } \\
\text { like protein p }\end{array}$ & -1.32 & -5.99 & -3.65 & gi|194223000 & 39011.2 & 5.56 & 6 & 50 & 0 & & \\
\hline $\begin{array}{l}\text { Chain A, crystal } \\
\text { structure of apo- } \\
\text { bovine alpha- } \\
\text { lactalbumin }\end{array}$ & 1.27 & -5.52 & -2.12 & gi|12084466 & 14176.8 & 4.8 & 7 & 218 & 100 & 139 & 100 \\
\hline
\end{tabular}




\begin{tabular}{|c|c|c|c|c|c|c|c|c|c|c|c|}
\hline $\begin{array}{l}\text { Top ranked protein } \\
\text { name (species) }\end{array}$ & $\begin{array}{l}\text { Ratio bull } \\
\mathrm{C} / \text { bull } \mathrm{A}\end{array}$ & $\begin{array}{l}\text { Ratio bull } \\
\text { D/bull B }\end{array}$ & $\begin{array}{l}\text { Average } \\
\text { ratio }\end{array}$ & $\begin{array}{l}\text { Accession } \\
\text { no. }\end{array}$ & $\begin{array}{l}\text { Protein } \\
\text { MW }\end{array}$ & $\begin{array}{l}\text { Protein } \\
\text { PI }\end{array}$ & $\begin{array}{l}\text { Pep. } \\
\text { count }\end{array}$ & $\begin{array}{l}\text { Protein } \\
\text { score }\end{array}$ & $\begin{array}{l}\text { Protein } \\
\text { score } \\
\text { C. I. \% }\end{array}$ & $\begin{array}{l}\text { Total } \\
\text { ion } \\
\text { score }\end{array}$ & $\begin{array}{l}\text { Total } \\
\text { ion } \\
\text { C. I. \% }\end{array}$ \\
\hline $\begin{array}{l}\text { Sperm acrosome } \\
\text { associated } 5 \text { [bos } \\
\text { taurus] }\end{array}$ & -1.26 & -2.45 & -1.85 & gi|94966873 & 17568.2 & 5.55 & 4 & 127 & 100 & 91 & 100 \\
\hline $\begin{array}{l}\text { PREDICTED: similar } \\
\text { to sp32 [bos } \\
\text { taurus] }\end{array}$ & -1.48 & -2.51 & -1.99 & gi|194666681 & 61196.7 & 5.11 & 6 & 563 & 100 & 535 & 100 \\
\hline $\begin{array}{l}\text { Protease, serine, } \\
2 \text { [rattus } \\
\text { norvegicus] }\end{array}$ & 1.63 & 1.27 & 1.45 & gi|6981420 & 25942.7 & 4.71 & 1 & 68 & 87.2 & 61 & 99.6 \\
\hline $\begin{array}{l}\text { Thioredoxin } \\
\text { domain } \\
\text { containing } 3 \\
\text { (spermatozoa) } \\
\text { [bos taurus] }\end{array}$ & -1.34 & -1.49 & -1.42 & gi|114053199 & 46889.1 & 4.94 & 17 & 269 & 100 & 134 & 100 \\
\hline $\begin{array}{l}\text { Acrosomal vesicle } \\
\text { protein } 1 \text { [bos } \\
\text { taurus] }\end{array}$ & 1.27 & -2.08 & -1.41 & gi|115495399 & 28934.4 & 4.53 & 6 & 100 & 100 & 60 & 99.9 \\
\hline
\end{tabular}

Table 2. Ingenuity Canonical Pathways using IPA. The IPA results of canonical pathways were obtained using the 2D-DIGE data and sorted by the significance level of the canonical pathways. A total of 47 canonical pathways with their p-value and related proteins were represented here

\begin{tabular}{|c|c|c|c|}
\hline Ingenuity canonical pathways & $\log (\mathrm{p}$-value $)$ & Ratio & Molecules \\
\hline Glycolysis/gluconeogenesis & $4.96 \mathrm{E} 00$ & $4.55 \mathrm{E}-02$ & $\begin{array}{l}\text { PGK2,ENO1,GAPDHS,LDHAL6B } \\
\end{array}$ \\
\hline 14-3-3-mediated Signaling & 3.05E00 & $2.46 \mathrm{E}-02$ & TUBB2C,YWHAZ,TUBA3C/TUBA3D \\
\hline Propanoate metabolism & $2.43 \mathrm{E} 00$ & $3.51 \mathrm{E}-02$ & LDHAL6B,ACADS \\
\hline Purine metabolism & 2.05E00 & $1.11 \mathrm{E}-02$ & NT5C1B,HSPD1,PDE6D \\
\hline Mitochondrial dysfunction & $1.72 \mathrm{E} 00$ & $1.47 \mathrm{E}-02$ & SOD2,CYC1 \\
\hline $\begin{array}{l}\text { Aldosterone signaling in } \\
\text { epithelial cells }\end{array}$ & $1.59 \mathrm{E} 00$ & $1.23 \mathrm{E}-02$ & HSPB9,HSPD1 \\
\hline $\begin{array}{l}\text { Germ cell-sertoli sell junction } \\
\text { signaling }\end{array}$ & $1.58 \mathrm{E} 00$ & $1.24 \mathrm{E}-02$ & TUBB2C,TUBA3C/TUBA3D \\
\hline $\begin{array}{l}\text { Phenylalanine, tyrosine and } \\
\text { tryptophan biosynthesis }\end{array}$ & $1.57 \mathrm{E} 00$ & $5.88 \mathrm{E}-02$ & ENO1 \\
\hline Gap junction signaling & $1.56 \mathrm{E} 00$ & 1.19E-02 & TUBB2C,TUBA3C/TUBA3D \\
\hline Riboflavin metabolism & $1.5 \mathrm{E} 00$ & $5 \mathrm{E}-02$ & ACP1 (includes EG:11431) \\
\hline $\begin{array}{l}\text { Sertoli cell-sertoli cell } \\
\text { junction signaling }\end{array}$ & $1.48 \mathrm{E} 00$ & $1.05 \mathrm{E}-02$ & TUBB2C,TUBA3C/TUBA3D \\
\hline $\begin{array}{l}\text { Breast cancer regulation by } \\
\text { stathmin } 1\end{array}$ & $1.42 \mathrm{E} 00$ & 9.95E-03 & TUBB2C,TUBA3C/TUBA3D \\
\hline $\begin{array}{l}\text { Protein ubiquitination } \\
\text { pathway }\end{array}$ & 1.19E00 & 7.41E-03 & HSPB9,HSPD1 \\
\hline Galactose metabolism & $1.18 \mathrm{E} 00$ & $2.33 \mathrm{E}-02$ & LALBA \\
\hline $\begin{array}{l}\text { Cell cycle: G2/M DNA damage } \\
\text { checkpoint regulation }\end{array}$ & 1.17E00 & $2.04 \mathrm{E}-02$ & YWHAZ \\
\hline Retinol metabolism & 1.17E00 & 2.27E-02 & NT5C1B \\
\hline$\beta$-alanine metabolism & $1.14 \mathrm{E} 00$ & $2.13 \mathrm{E}-02$ & ACADS \\
\hline Phototransduction pathway & $1.09 \mathrm{E} 00$ & $1.79 \mathrm{E}-02$ & PDE6D \\
\hline Cysteine metabolism & $1.09 \mathrm{E} 00$ & $1.89 \mathrm{E}-02$ & LDHAL6B \\
\hline Protein kinase a signaling & $1.06 \mathrm{E} 00$ & $6.27 \mathrm{E}-03$ & YWHAZ,PDE6D \\
\hline $\begin{array}{l}\text { Myc mediated apoptosis } \\
\text { signaling }\end{array}$ & $1.05 \mathrm{E} 00$ & $1.64 \mathrm{E}-02$ & YWHAZ \\
\hline Butanoate metabolism & $1.04 \mathrm{E} 00$ & 1.67E-02 & ACADS \\
\hline ERK5 signaling & $1.02 \mathrm{E} 00$ & $1.59 \mathrm{E}-02$ & YWHAZ \\
\hline Pyruvate metabolism & $9.99 \mathrm{E}-01$ & $1.52 \mathrm{E}-02$ & LDHAL6B \\
\hline $\begin{array}{l}\text { Valine, leucine, and isoleucine } \\
\text { degradation }\end{array}$ & 9.99E-01 & $1.52 \mathrm{E}-02$ & ACADS \\
\hline PDGF signaling & $9.69 \mathrm{E}-01$ & 1.37E-02 & ACP1 (includes EG:11431) \\
\hline Aminosugars metabolism & $9.69 \mathrm{E}-01$ & $1.41 \mathrm{E}-02$ & PDE6D \\
\hline TR/RXR activation & $8.96 \mathrm{E}-01$ & $1.12 \mathrm{E}-02$ & ENO1 \\
\hline Axonal guidance signaling & 8.9E-01 & $4.71 \mathrm{E}-03$ & TUBB2C,TUBA3C/TUBA3D \\
\hline
\end{tabular}


Table 2. Continued

\begin{tabular}{|c|c|c|c|}
\hline Ingenuity canonical pathways & $\log (p-v a l u e)$ & Ratio & Molecules \\
\hline IGF-1 signaling & $8.34 \mathrm{E}-01$ & $9.62 \mathrm{E}-03$ & YWHAZ \\
\hline $\begin{array}{l}\text { Nicotinate and nicotinamide } \\
\text { metabolism }\end{array}$ & $8.26 \mathrm{E}-01$ & $9.9 \mathrm{E}-03$ & NT5C1B \\
\hline $\begin{array}{l}\text { Type I diabetes mellitus } \\
\text { Signaling }\end{array}$ & 7.95E-01 & $8.55 \mathrm{E}-03$ & HSPD1 \\
\hline PI3K/AKT signaling & 7.61E-01 & $7.52 \mathrm{E}-03$ & YWHAZ \\
\hline p70S6K signaling & 7.47E-01 & 7.87E-03 & YWHAZ \\
\hline Fatty acid metabolism & $7.47 \mathrm{E}-01$ & $8.06 \mathrm{E}-03$ & ACADS \\
\hline $\begin{array}{l}\text { Cardiac } \beta \text {-adrenergic } \\
\text { signaling }\end{array}$ & 7.2E-01 & 7.19E-03 & PDE6D \\
\hline Relaxin signaling & 7.14E-01 & $6.9 \mathrm{E}-03$ & PDE6D \\
\hline Pyrimidine metabolism & 6.94E-01 & 7.09E-03 & NT5C1B \\
\hline Oxidative phosphorylation & $6.86 \mathrm{E}-01$ & $6.94 \mathrm{E}-03$ & CYC1 \\
\hline $\begin{array}{l}\text { Acute phase response } \\
\text { signaling }\end{array}$ & $6.29 \mathrm{E}-01$ & $5.81 \mathrm{E}-03$ & SOD2 \\
\hline RAR activation & $6.2 \mathrm{E}-01$ & $5.65 \mathrm{E}-03$ & NT5C1B \\
\hline Ephrin receptor signaling & $6.15 \mathrm{E}-01$ & $5.1 \mathrm{E}-03$ & ACP1 (includes EG:11431) \\
\hline $\begin{array}{l}\text { NRF2-mediated oxidative } \\
\text { stress response }\end{array}$ & $6 \mathrm{E}-01$ & $5.26 \mathrm{E}-03$ & SOD2 \\
\hline ERK/MAPK signaling & 5.92E-01 & $5.05 \mathrm{E}-03$ & YWHAZ \\
\hline cAMP-mediated signaling & $5.38 \mathrm{E}-01$ & 4.65E-03 & PDE6D \\
\hline $\begin{array}{l}\text { Role of macrophages, } \\
\text { fibroblasts and endothelial } \\
\text { cells in rheumatoid arthritis }\end{array}$ & 4.11E-01 & $3.04 \mathrm{E}-03$ & PRSS1/PRSS3 \\
\hline $\begin{array}{l}\text { G-Protein coupled receptor } \\
\text { signaling }\end{array}$ & $2.48 \mathrm{E}-01$ & 1.92E-03 & PDE6D \\
\hline
\end{tabular}

Table 3. Networks created by IPA analysis. The data obtained from the 2D-DIGE analysis were analyzed using IPA software and sorted by the significance level of the networks. The interactions of the proteomics were generated by overlaying the first and the second networks

\begin{tabular}{|c|c|c|c|}
\hline Top functions & Score & Focus molecules & Molecules in network \\
\hline $\begin{array}{l}\text { Free radical scavenging, cancer, } \\
\text { hematological disease }\end{array}$ & 33 & 13 & $\begin{array}{l}\text { AARS,ACADS,ACP1 (includes } \\
\text { EG:11431),ACPP,Akt,Alpha } \\
\text { tubulin,CD3, CENPJ, } \\
\text { CYC1,Cytochrome } \\
\text { c,ENO1,Enolase, } \\
\text { ERK1/2,GZMK, HSP, HSPB9, } \\
\text { HSPD1,Jnk,LALBA, mannitol, } \\
\text { MLXIP,ODF1,PACS2,PEBP4,PI3K } \\
\text { (complex), PRSS1/PRSS3, } \\
\text { SIRT3,SOD2,TAOK2,TPD52 } \\
\text {,TUBA3C/TUBA3D, TUBB1, } \\
\text { TUBB2C,Tubulin, YWHAZ }\end{array}$ \\
\hline $\begin{array}{l}\text { Cellular assembly and } \\
\text { organization, cellular } \\
\text { development, embryonic } \\
\text { development }\end{array}$ & 9 & 3 & ACRV1,ACTL7A,Odf2,YBX2 \\
\hline $\begin{array}{l}\text { Carbohydrate metabolism, small } \\
\text { molecule biochemistry, antigen } \\
\text { presentation }\end{array}$ & 3 & 1 & A2M,SPACA3 \\
\hline $\begin{array}{l}\text { Cell-to-cell signaling and } \\
\text { interaction, reproductive } \\
\text { system development, and } \\
\text { function, cellular development }\end{array}$ & 3 & 1 & Gstp1 (includes others),WBP2NL \\
\hline $\begin{array}{l}\text { Embryonic development, } \\
\text { endocrine system development } \\
\text { and function, organ } \\
\text { development }\end{array}$ & 3 & 1 & $\begin{array}{l}\text { HNF1A,PGCP,TGFB1 (includes } \\
\text { EG:21803) }\end{array}$ \\
\hline
\end{tabular}


Table 3. Continued

\begin{tabular}{|c|c|c|c|}
\hline Top functions & Score & Focus molecules & Molecules in network \\
\hline $\begin{array}{l}\text { Cell cycle, cellular compromise, } \\
\text { cellular growth and } \\
\text { proliferation }\end{array}$ & 3 & 1 & ACRBP,NUMA1,progesterone \\
\hline $\begin{array}{l}\text { RNA damage and repair, gene } \\
\text { expression, RNA post- } \\
\text { transcriptional modification }\end{array}$ & 3 & 1 & $\begin{array}{l}\text { HNRNPD,L-lactate } \\
\text { dehydrogenase,LDHAL6B }\end{array}$ \\
\hline $\begin{array}{l}\text { Drug metabolism, lipid } \\
\text { metabolism, small molecule } \\
\text { biochemistry }\end{array}$ & 3 & 1 & 5'-nucleotidase,NT5C1B,RDH \\
\hline $\begin{array}{l}\text { Genetic disorder, neurological } \\
\text { disease, cell morphology }\end{array}$ & 2 & 1 & $\begin{array}{l}\text { CACNA1E,E2F4,E2f,EFHC1,TEX11,V } \\
\text { oltage Gated Calcium Channel }\end{array}$ \\
\hline $\begin{array}{l}\text { Cell death, liver necrosis/cell } \\
\text { death, cellular movement }\end{array}$ & 2 & 1 & $\begin{array}{l}\text { ATP,GAPDHS,glyceraldehyde-3- } \\
\text { phosphate dehydrogenase (pho } \\
\text { sphorylating),HSPA2,MAPK3,MI } \\
\text { TF,NTHL1,SH3BP4 }\end{array}$ \\
\hline $\begin{array}{l}\text { Neurological disease, genetic } \\
\text { disorder, organismal injury and } \\
\text { abnormalities }\end{array}$ & 2 & 1 & $\begin{array}{l}\text { APP,Crem,DNMT3A,DNMT3B,FGF } \\
\text { 2,MAPT,PAPOLB,PBX4,PDPK1,PG } \\
\text { K2,Pgk,PSEN1,SP3,UBC }\end{array}$ \\
\hline $\begin{array}{l}\text { Cell-to-cell signaling and } \\
\text { interaction, cellular assembly } \\
\text { and organization, tissue } \\
\text { development }\end{array}$ & 2 & 1 & $\begin{array}{l}\text { 3',5'-cyclic-GMP } \\
\text { phosphodiesterase,3',5'-cyclic- } \\
\text { nucleotide phosphodiesterase, } \\
\text { ARL1,ARL2, ARL3,ARL15, } \\
\text { C9orf25, Ca2+,CDC42,CETN3,G } \\
\text { RK1,GRK7,HRAS,KRAS,NRAS,Pd } \\
\text { e,PDE6 d),PDE6D,PTGIR, RAB13, } \\
\text { RAB18, RAD23A, RAP1A,RAP2B, } \\
\text { RHEB,RHOA,RHOB, RND1,RPGR }\end{array}$ \\
\hline
\end{tabular}

statistically significant by enriching above the threshold as shown (Figure 3a). Based on the DAVID software, glycolysis/gluconeogenesis is the first cluster with 3.17 of enrichment score and enolase 1 was the first significantly expressed protein in this pathway (Figure $3 \mathrm{~b}$ ) the same pathway was also confirmed by IPA as significant $(p<0.0001)$ in the canonical pathway (Figure 3a).

Additionally, free radical scavenging and cellular assembly or organization, cellular development, and embryonic development networks were identified to be first and second networks, respectively (Table 3 ). The first and second networks had a ratio containing focused molecules over score; 13/33 and $3 / 9$, respectively. Based on the IPA results, most of the proteins in our sperm proteomics data were found to be enzymes with important functions. Their locations and functions were listed in Table 4. The final interactome was created by overlaying the two networks mentioned earlier (Figure 4) by selecting differentially expressed two proteins: outer dense fiber of sperm tails 2 (ODF-2) from the first network and manganese superoxide dismutase (SOD) from the second network. According to 2D-DIGE results, MnSOD was 4.65 times more abundant in spermatozoa from relatively higher 
a

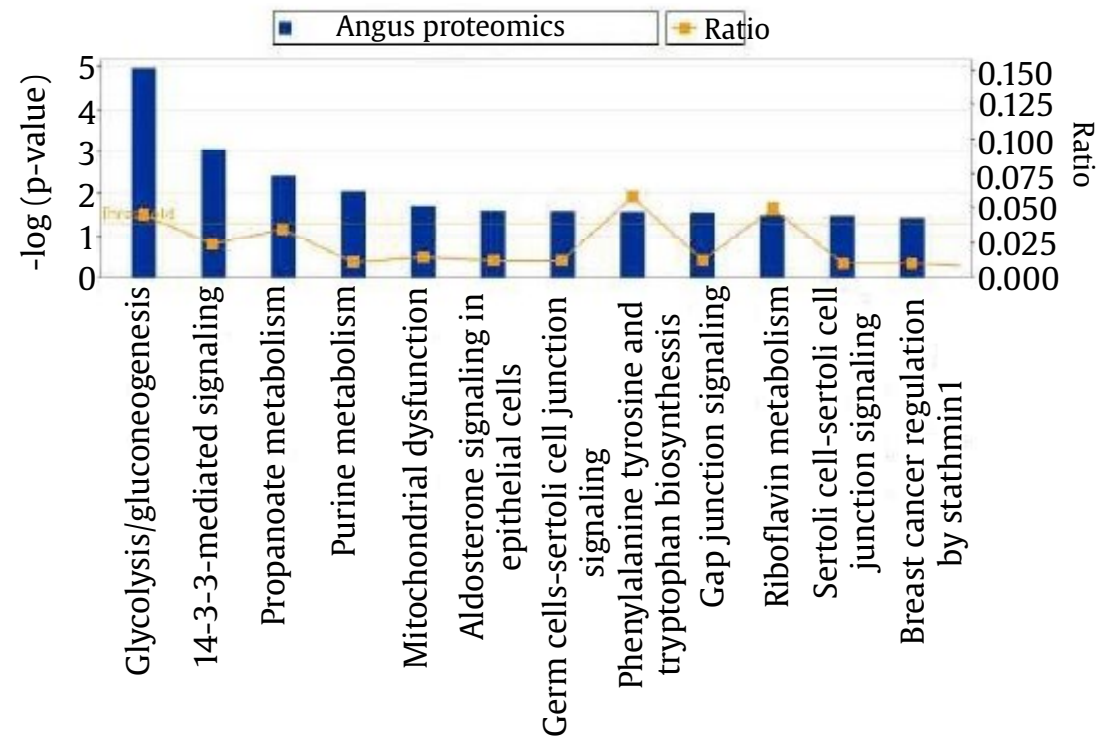

b

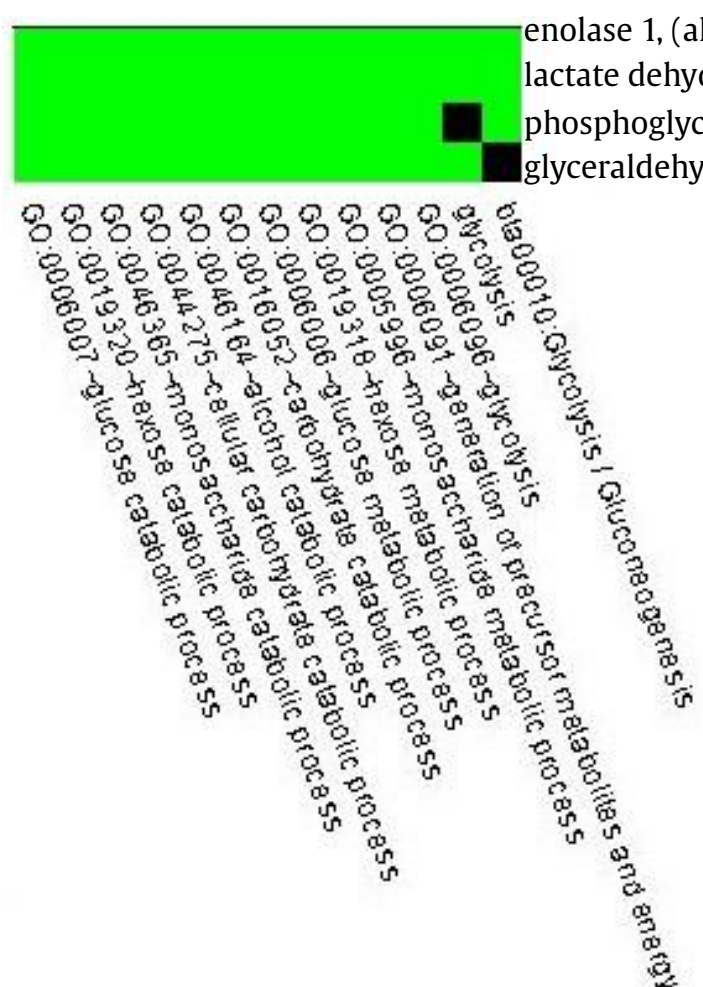

Figure 3. IPA canonical pathways and proteins of cluster 1 by DAVID. (a) this figure shows 12 canonical pathways generated using IPA, which were statistically significant by enriching above the threshold (out of 47). The bars in the graph represent the total molecules involved in these pathways while the ratio (yellow line) shows the proteins given for each pathway in the data, (b) the glycolysis is shown to be the first cluster of functional gene annotation according to DAVID bioinformatics tool. In this figure, the horizontal axis demonstrates the functions of the related proteins that are represented in the vertical axis 
Table 4. Protein cellular locations and physiology. The locations and functions of the detected sperm proteins detected were generated using IPA analyses

\begin{tabular}{|c|c|c|c|c|}
\hline Id & Symbol & Entrez gene name & Location & Type(s) \\
\hline 77735757 & ACADS & acyl-CoA dehydrogenase, $\mathrm{C}-2$ to $\mathrm{C}-3$ short chain & Cytoplasm & enzyme \\
\hline 148744160 & ACP1 (includes EG:11431) & acid phosphatase 1 , soluble & Cytoplasm & phosphatase \\
\hline 194666681 & ACRBP & acrosin binding protein & $\begin{array}{l}\text { Extracellular } \\
\text { Space }\end{array}$ & other \\
\hline 115495399 & ACRV1 & acrosomal vesicle protein 1 & Cytoplasm & other \\
\hline 84370183 & ACTL7A & actin-like 7A & Nucleus & other \\
\hline 61878077 & ACTRT1 & actin-related protein $\mathrm{T} 1$ & Cytoplasm & other \\
\hline 84000199 & ACTRT2 & actin-related protein $\mathrm{T} 2$ & unknown & other \\
\hline 115495817 & C15orf26 & chromosome 15 open reading frame 26 & unknown & other \\
\hline 76650703 & EFHC1 & EF-hand domain (C-terminal) containing 1 & Cytoplasm & other \\
\hline 4927286 & ENO1 & enolase 1, (alpha) & Cytoplasm & $\begin{array}{l}\text { transcription } \\
\text { regulator }\end{array}$ \\
\hline 110626121 & GAPDHS & $\begin{array}{l}\text { glyceraldehyde-3-phosphate dehydrogenase, } \\
\text { spermatogenic }\end{array}$ & Cytoplasm & enzyme \\
\hline 94966950 & HSPB9 & heat shock protein, alpha-crystallin-related, B9 & Cytoplasm & other \\
\hline 156120505 & IZUMO4 & IZUMO family member 4 & unknown & other \\
\hline 78369344 & LDHAL6B & lactate dehydrogenase A-like 6B & Cytoplasm & enzyme \\
\hline 84370143 & NT5C1B & 5'-nucleotidase, cytosolic IB & Cytoplasm & phosphatase \\
\hline 84000345 & Odf2 & outer dense fiber of sperm tails 2 & Cytoplasm & other \\
\hline 27806061 & PDE6D & $\begin{array}{l}\text { phosphodiesterase 6D, cGMP-specific, rod, } \\
\text { delta }\end{array}$ & Cytoplasm & enzyme \\
\hline 77735827 & PEBP4 & phosphatidylethanolamine-binding protein 4 & Cytoplasm & other \\
\hline 115495837 & PGCP & plasma glutamate carboxypeptidase & $\begin{array}{l}\text { Extracellular } \\
\text { Space }\end{array}$ & peptidase \\
\hline 174840786 & PGK2 & phosphoglycerate kinase 2 & Cytoplasm & kinase \\
\hline 6981420 & PRSS1/PRSS3 & protease, serine, 1 (trypsin 1$)$ & $\begin{array}{l}\text { Extracellular } \\
\text { Space }\end{array}$ & peptidase \\
\hline 7555818 & SOD2 & superoxide dismutase 2 , mitochondrial & Cytoplasm & enzyme \\
\hline 157279923 & SPACA3 & sperm acrosome associated 3 & Cytoplasm & enzyme \\
\hline 149773556 & TEKT3 & tektin 3 & Cytoplasm & other \\
\hline 6678465 & TUBA3C/TUBA3D & tubulin, alpha $3 c$ & Cytoplasm & other \\
\hline 14124960 & TUBB2C & tubulin, beta $2 \mathrm{C}$ & Cytoplasm & other \\
\hline 126723634 & WBP2NL & WBP2 N-terminal like & Cytoplasm & other \\
\hline 68085578 & YWHAZ & $\begin{array}{l}\text { tyrosine } 3 \text {-monooxygenase/tryptophan } \\
\text { 5-monooxygenase activation protein, zeta } \\
\text { polypeptide }\end{array}$ & Cytoplasm & enzyme \\
\hline
\end{tabular}

fertility bulls (Bulls A and B) compared to that from their lower fertility counterparts (Bulls $C$ and D) in the experimental population. On the other hand, ODF2 protein was up regulated in spermatozoa from low fertility animals (Bulls C and D) although their expression levels varied in the individual bulls. The average of protein expression ratios obtained from relatively lower fertility bulls (Bulls $C$ and $D$ ) over high fertility bulls (Bulls A and B) (Table 1).

\subsection{Sperm Proteins as Fertility Markers and Likely Protein-Protein Interaction}

In search for potential fertility markers, we have determined sperm proteins that have been identified in this study and through the literature search. The fertility makers are mainly chromatin/nuclear proteins, seminal plasma proteins, proteins in acrosome, proteins which regulate ATP synthesis, capacitation related proteins, and sperm cytoskeletal proteins (Table 5). 


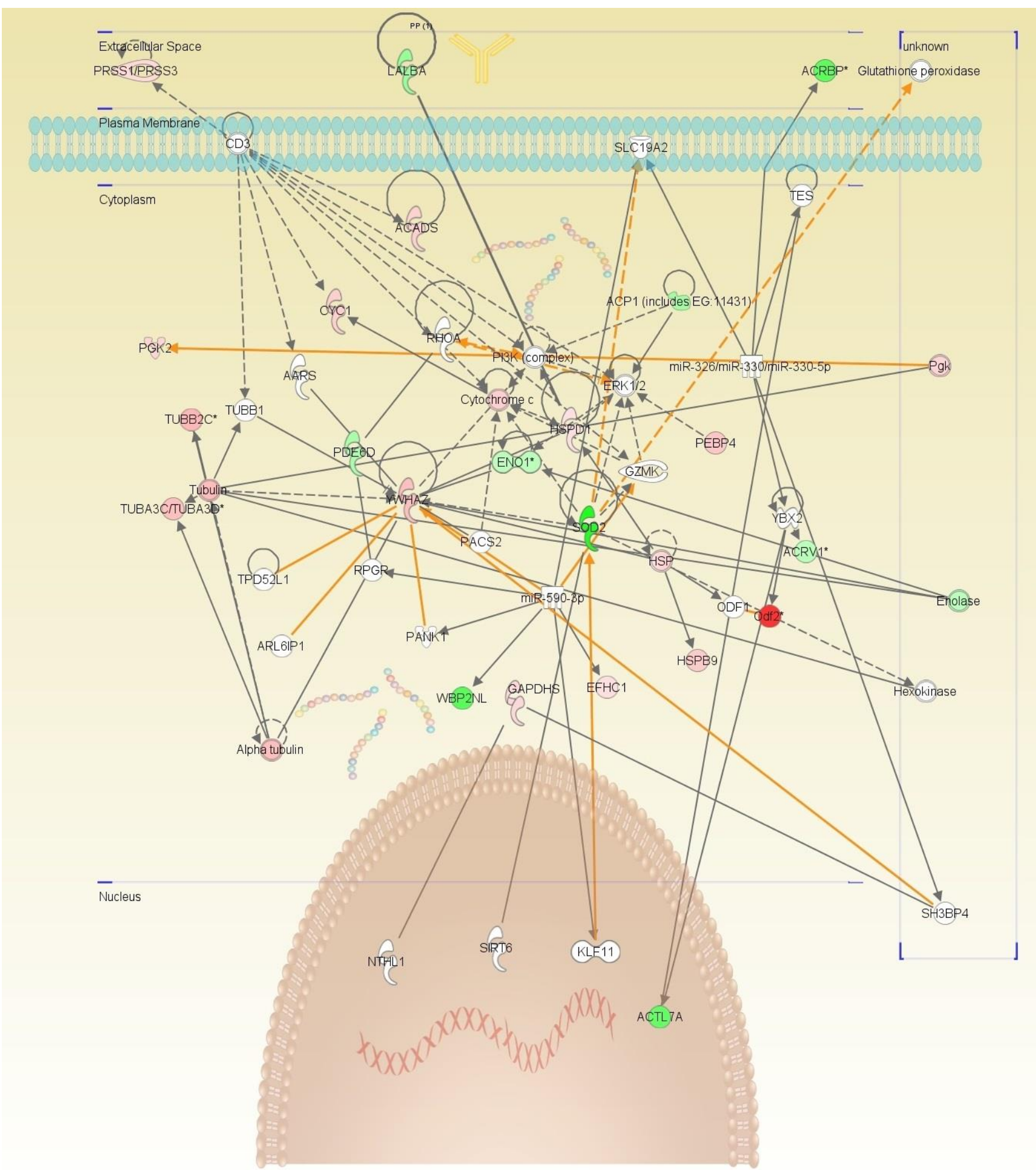

Figure 4. The merged interactome by IPA Networks 1 and 2. The final interactome was created by overlaying of these two networks free radical scavenging and cellular assembly or organization, cellular development, and embryonic development networks. The proteins and their interactions between others including as well as their locations in the cell are also included in the figure. The red and green colors of each protein represent up-regulated and down-regulated proteins in spermatozoa from lower fertility bulls (Bull C and D), respectively 
Table 5. Comparison of sperm protein markers reported among different bovine species belonging to different categories of sperm physiology pathways in current literature

\begin{tabular}{|c|c|c|c|c|}
\hline $\begin{array}{l}\text { Category of } \\
\text { protein }\end{array}$ & Protein name & Function & $\begin{array}{l}\text { Holstein and other } \\
\text { bovine bull sperm }\end{array}$ & $\begin{array}{l}\text { Angus bull } \\
\text { sperm }\end{array}$ \\
\hline \multirow[t]{4}{*}{$\begin{array}{l}\text { Sperm } \\
\text { chromatin } \\
\text { proteins }\end{array}$} & Protamines (PRM) & $\begin{array}{l}\text { Substitute for histones in the sperm chromatin } \\
\text { spermatid to sperm development phase of } \\
\text { spermatogenesis. They compact sperm DNA } \\
\text { into a highly condensed, stable and inactive } \\
\text { complex }\end{array}$ & $\begin{array}{l}\text { Holstein } \\
\quad \text { (Fortes et al. 2014; } \\
\text { Dogan et al. 2015) }\end{array}$ & No reports \\
\hline & HIST1H2BA/ TH2B & $\begin{array}{l}\text { Testis specific histone variant specifically } \\
\text { required to direct the transformation of } \\
\text { dissociating nucleosomes to protamine in } \\
\text { male germ cells }\end{array}$ & $\begin{array}{l}\text { Holstein } \\
\text { (Kutchy et al. } \\
\text { 2017) }\end{array}$ & No reports \\
\hline & H3K27ac & $\begin{array}{l}\text { Functions as histone acetyltransferase and } \\
\text { regulates transcription via chromatin } \\
\text { remodeling. Acetylates all four core histones } \\
\text { in nucleosomes }\end{array}$ & $\begin{array}{l}\text { Holstein } \\
\text { (Kutchy et al. } \\
\text { 2018) }\end{array}$ & No reports \\
\hline & H3K27me3 & $\begin{array}{l}\text { Catalytic subunit of the PRC2/EED-EZH2 } \\
\text { complex, which methylates 'Lys-9'(H3K9me) } \\
\text { and 'Lys- } 27 \text { ' (H3K27me) of histone H3, } \\
\text { leading to transcriptional repression of the } \\
\text { affected target gene }\end{array}$ & $\begin{array}{l}\text { Holstein } \\
\text { (Kutchy et al. } \\
\text { 2018) }\end{array}$ & No reports \\
\hline $\begin{array}{l}\text { Seminal } \\
\text { plasma } \\
\text { proteins }\end{array}$ & Osteopontin & $\begin{array}{l}\text { Binds tightly to hydroxyapatite and appears } \\
\text { to form an integral part of the mineralized } \\
\text { matrix. Probably important to cell-matrix } \\
\text { interaction }\end{array}$ & $\begin{array}{l}\text { Holstein } \\
\text { (Cancel et al. } \\
\text { 1997; Cancel et al. } \\
\text { 1999) }\end{array}$ & No reports \\
\hline \multirow[t]{2}{*}{$\begin{array}{l}\text { Acrosomal } \\
\text { proteins }\end{array}$} & $\begin{array}{l}\text { Acrosomal } \\
\text { tyrosine- } \\
\text { phosphorylated } \\
\text { proteins }\end{array}$ & $\begin{array}{l}\text { Role in acrosomal formation of spermatids } \\
\text { during spermiogenesis }\end{array}$ & $\begin{array}{l}\text { Japanese } \\
\text { Black cattle } \\
\text { (Harayama et al. } \\
\text { 2010) }\end{array}$ & No reports \\
\hline & IZUMMO1 & Fusion of sperm to egg plasma membrane & $\begin{array}{l}\text { Japanese } \\
\text { Black cattle } \\
\text { (Fukuda et al. } \\
\text { 2016) }\end{array}$ & No reports \\
\hline \multirow[t]{3}{*}{$\begin{array}{l}\text { ATP } \\
\text { synthesis } \\
\text { proteins }\end{array}$} & $\begin{array}{l}\text { Adenylate kinase } 1 \\
\text { (AK1) }\end{array}$ & $\begin{array}{l}\text { Catalyzes the reversible transfer of the terminal } \\
\text { phosphate group between ATP and AMP. } \\
\text { Plays an important role in cellular energy } \\
\text { homeostasis and in adenine nucleotide } \\
\text { metabolism }\end{array}$ & $\begin{array}{l}\text { Holstein (D’Amours } \\
\text { et al. 2012) }\end{array}$ & No reports \\
\hline & Enolase 1 (ENO1) & $\begin{array}{l}\text { Multifunctional enzyme, plays part in } \\
\text { glycolysis, plays a part in various processes } \\
\text { such as growth control, hypoxia tolerance } \\
\text { and allergic responses. May also function } \\
\text { in the intravascular and pericellular } \\
\text { fibrinolytic system due to its ability to serve } \\
\text { as a receptor and activator of plasminogen } \\
\text { on the cell surface of several cell-types } \\
\text { such as leukocytes and neurons. Stimulates } \\
\text { immunoglobulin production }\end{array}$ & $\begin{array}{l}\text { Hanwoo } \\
\quad \text { (Park et al. 2012) }\end{array}$ & No reports \\
\hline & $\begin{array}{l}\text { ATP synthase } \\
\mathrm{H}+\text { transporting } \\
\text { mitochondrial F1 } \\
\text { complex } \beta \text { subunit } \\
\text { (ATP5B) }\end{array}$ & $\begin{array}{l}\text { ATP synthesis and hydrolysis of proton } \\
\text { transport }\end{array}$ & $\begin{array}{l}\text { Holstein (Peddinti et } \\
\quad \text { al. 2008) }\end{array}$ & No reports \\
\hline $\begin{array}{l}\text { Capacitation } \\
\text { proteins }\end{array}$ & $\mathrm{Na}+/ \mathrm{K}+-\mathrm{ATPase}$ & $\begin{array}{l}\text { Its role is to create the electrochemical } \\
\text { gradient of sodium and potassium, providing } \\
\text { the energy for active transport of various } \\
\text { nutrients }\end{array}$ & $\begin{array}{l}\text { Holstein } \\
\text { (Thundathil et al. } \\
\text { 2006) }\end{array}$ & No reports \\
\hline
\end{tabular}


Table 5. Continued

\begin{tabular}{|c|c|c|c|c|}
\hline $\begin{array}{l}\text { Category of } \\
\text { protein }\end{array}$ & Protein name & Function & $\begin{array}{l}\text { Holstein and other } \\
\text { bovine bull sperm }\end{array}$ & $\begin{array}{l}\text { Angus bull } \\
\text { sperm }\end{array}$ \\
\hline $\begin{array}{l}\text { Cytoskeletal } \\
\text { proteins }\end{array}$ & $\begin{array}{l}\text { Outer dense } \\
\text { protein fiber } 2 \\
\text { (ODF2) }\end{array}$ & $\begin{array}{l}\text { A major component of sperm tail outer } \\
\text { dense fibers (ODF). ODFs are filamentous } \\
\text { structures located on the outside of the } \\
\text { axoneme in the midpiece and principal piece } \\
\text { of the mammalian sperm tail and may help } \\
\text { to maintain the passive elastic structures } \\
\text { and elastic recoil of the sperm tail. May have } \\
\text { a modulating influence on sperm motility. } \\
\text { Functions as a general scaffold protein that is } \\
\text { specifically localized at the distal/subdistal } \\
\text { appendages of mother centrioles }\end{array}$ & $\begin{array}{l}\text { Holstein } \\
\quad \text { (Petersen et al. } \\
\text { 1999; Wang et al. } \\
\text { 2014) }\end{array}$ & $\begin{array}{l}\text { Current } \\
\text { study }\end{array}$ \\
\hline $\begin{array}{l}\text { Other } \\
\text { proteins }\end{array}$ & $\begin{array}{l}\text { Super oxide } \\
\quad \text { dismutase (SOD) }\end{array}$ & $\begin{array}{l}\text { Destroys radicals which are normally produced } \\
\text { within the cells and which are toxic to } \\
\text { biological systems }\end{array}$ & $\begin{array}{l}\text { Holstein } \\
\quad \text { (Bansal and } \\
\text { Bilaspuri 2008) }\end{array}$ & $\begin{array}{r}\text { Current } \\
\text { study }\end{array}$ \\
\hline
\end{tabular}

\section{Discussion}

Molecular and cellular attributes of sperm are important for fertilization, egg activation and embryonic development. Some bulls that produce high numbers of spermatozoa with normal morphology exhibit low fertility after hundreds of AI (DeJarnette and Marshall 2005). Despite the importance of male fertility in reproduction for both basic and applied science, there is no sufficient method to determine sperm quality other than conventional semen analysis. Indeed, traditional approaches to estimate male fertility such as evaluating of sperm morphology and motility might not be accurate all the time (Bartoov et al. 1993). Molecular mechanisms of how male fertility can be fully determined by evaluating the sperm quality still remain a mystery. The objective of this study was to identify differentially expressed proteins in spermatozoa from bulls with different fertility taking advantage of both wet lab and computational biology and bioinformatics approaches.

While proteomics is an important highthroughput method providing a panoramic view of proteomes in the cell, bioinformatics is a powerful approach to predict and discover the functions and interactions of the given proteins. Sperm proteome profiling has been reported in human (MartinezHeredia et al. 2006; Li et al. 2007), in murine (Cao et al. 2006; Baker et al. 2008a, 2008b), in porcine (van Gestel et al. 2007) and in bovine (Lalancette et al. 2006; Peddinti et al. 2008; D'Amours et al. 2010) and results generated by these researchers provided important insights about identities of diverse proteins. Previously, expressions of nine proteins, including two isoforms of epididymal sperm-binding protein E12 and proteasome subunit $\alpha$ type- 6 , were shown to be differentially expressed among high and low fertility Holstein bulls. Recently, using sperm from low vs. High fertility bulls, three proteins; enolase (ENO1), voltage dependent anion channel 2 (VDAC2), and ubiquinol-cytochrome-c reductase complex core protein 2 (UQCRC2) were detected to be the fertility markers in bulls (Park et al. 2012; Park et al. 2013; Kwon et al. 2015a). Our group previously showed that the expression of certain proteins in spermatozoa from high-fertility Holstein bulls was implicated in energy metabolism, cell communication, spermatogenesis, and cell motility (Peddinti et al. 2008). However, according to our literature search, sperm proteomics profiling of Angus bulls has been elusive.

In our study reported here, there were more than 80 sperm protein spots that notably differed among the bulls with varying fertility. By comparing the protein spot sequences to the databases, we identified most of these proteins. Our 2D-DIGE results demonstrated that ODF2 was up-regulated in spermatozoa from relatively low fertile bulls (Bulls C and D). ODF2 is a cytoskeletal structural protein in spermatozoa and it is abundantly present in flagella. Thus, it is associated with sperm morphology and motility, and that its absence or decreased expression leads to abnormal morphology and infertility (Petersen et al. 1999; Wang et al. 2014; Yoon et al. 2016). The structure of ODF2 protein is an $\alpha$-helical and is similar to leucine zipper motif (Brohmann et al. 1997). Three or four testis-specific transcripts 
of odf2 gene have been detected in rat and bull spermatozoa (Brohmann et al. 1997; Schalles et al. 1998) and mutations in odf2 gene are known to result certain tail abnormalities in spermatozoa (Tarnasky et al. 2010). Previously, ODF2 and Cenexin were shown to be the alternative splice variants of exon $3 \mathrm{~b}$ of odf2 in mouse testis (Huber et al. 2008). Our results from the 2D-DIGE experiments demonstrated the importance of ODF-2 in sperm motility and ultimately bull fertility and the results are supported by (Cao et al. 2006). Protein variations can be induced by additional posttranslational modifications such as phosphorylation, cleavage, and glycosylation (Flickinger et al. 2001). Indeed, our results showed that many of the differentially expressed protein spots corresponded to ODF2, suggesting the possible posttranslational modifications (PTM) occurring in this protein. For example, it was revealed that a tyrosine phosphorylation in sperm ODF2 took place during capacitation (Mariappa et al. 2010).

The other protein of significant function was SOD based on our 2D-DIGE and bioinformatics results. The SOD is an important antioxidant that dismutase $\mathrm{O}_{2}$ - into $\mathrm{H}_{2} \mathrm{O}_{2}$, improves cell survival by reducing the level of ROS. It is plausible that this increased expression of SOD reflects a defensive response to protect the spermatozoa against oxidative stress (Mruk et al. 2002; Fujii et al. 2003; Cui et al. 2008; Yoon et al. 2016). The SODs are scavenger antioxidants catalyzing the neutralization reaction of superoxide radicals into $\mathrm{H}_{2} \mathrm{O}_{2}$ and oxygen in the cell. Because of the cytoplasmic reduction and environmental changes, spermatozoa become vulnerable to oxidative stress in the course of spermatogenesis (Agarwal and Prabakaran 2005). On the other hand, SOD has also a protective effect against oxidation, enhancing sperm motility (Lindemann et al. 1988; Kobayashi et al. 1991). Likewise, there was an increase in sperm motility and viability and a decrease in the LPO levels when bull spermatozoa were subjected to $\mathrm{Mn}^{2+}$ treatment in presence of oxidative stress (Bansal and Bilaspuri 2008).

Another study showed that the expression of MnSOD in bovine blastocysts increased when the culture media was supplemented with fetal calf serum (FCS), which could improve cryotolerance of these blastocysts (Rizos et al. 2003). In addition, it was suggested that SOD activity in bovine spermatozoa might be a metabolic indicator of membrane integrity. Since the same study revealed a correlation between malondialdehyde production and SOD activity, measuring this enzyme in spermatozoa might predict oxidative stress-induced damage (Beconi et al. 1991). In contrast, a study concluded that male infertility was not related to the SOD activities in both human spermatozoa and seminal plasma where the semen was obtained from men with normozoospermia and oligoasthenozoospermia (Hsieh et al. 2002). However, fertility scores of human patients were not as reliable as those obtained from livestock animals. In another study, the MnSOD activity in human spermatozoa was detected to be negligible. However, compared to human blood plasma, the abundance of total SOD activity in the seminal plasma was 20 times higher. According to the same study, it was concluded that the minimal activity of SOD enzymes in spermatozoa might be the reason of its protection against internal and external superoxide radicals (Peeker et al. 1997).

We established here that MnSOD was upregulated in spermatozoa from relative higher fertile bulls (Bulls A and B) compared to their low fertile counterparts based on the 2D-DIGE results. Therefore, these differentially expressed proteins could potentially play key roles in spermatozoa and may be involved in male fertility and could be used to predict superior sires (Kwon et al. 2015a, 2015c). We concluded that the abundance of SOD in spermatozoa differs among the bulls with different fertility in a given population. This might be an indicator of excessive oxidative stress caused by cryopreservation or centrifugation in spermatozoa, affecting sperm motility and ultimately male fertility.

Protein based molecular markers provide reliable information about the elite sire as well as its progeny. However, comparing Angus cattle across other cattle breeds especially Holstein for recognizing the protein molecular markers for sire selection, we find no report for Angus. Different categories of sperm associated proteins are chromatin/nuclear proteins, seminal plasma proteins, proteins in acrosome, proteins which regulate ATP synthesis, capacitation related proteins, and sperm cytoskeletal proteins. We have report about the sperm chromatin related proteins as potential markers for selection (Fortes et al. 2014; Dogan et al. 2015; Kutchy et al. 2017; Kutchy et al. 2018) out of all these reported proteins no reports are available for Angus cattle one of the well reputed cattle breed in the USA. Therefore, we realize urgent need of selection of Angus bulls based on protein as markers of selection and hence 
dire need to report the potential protein markers in Angus sperm and related proteins.

In conclusion evaluating semen quality and predicting bull fertility are vital for precision livestock agriculture. With the increasing uses of artificial insemination bull effects on herd is becoming more prevalent. Low heritability of the fertility traits implies that much of the differences in bull fertility are related to environment, management, nutrition and epigenetics. As such, sperm functional genomes such as proteomes reflect sperm fertility, and the differentially expressed proteins in high fertility $v s$. Low fertility can be harnessed as potent fertility markers in sperm evaluation and marker assisted selection. There is a need for reliable phenotypic data in order to identify such fertility markers. Compared to the dairy cattle, there is a disparity of phenotypic data in beef cattle. To remedy this, beef producers should collect phenotypic data and keep records including the pedigree information. Through comparative biology, sperm fertility proteins identified in dairy bulls can be studied to determine to what extent the protein markers can be used for beef bulls. Sperm protein markers can be combined with other sperm parameters and used as complementary tests in genomic selection. Comprehensive studies aimed at sperm functional genome and epigenome in larger sample sizes during the entire year for multiple years are expected to further fundamental science and technology of bull fertility.

\section{Acknowledgements}

This study was funded in part by American Angus Association, Alta Genetics, Inc., Mississippi Agricultural Forestry Experiment Station and Netaji Subhas-Indian Council of Agricultural Research for International Fellowships 2015-2017, India (ICAR).

\section{References}

Agarwal A, Prabakaran SA. 2005. Mechanism, measurement, and prevention of oxidative stress in male reproductive physiology. Indian J Exp Biol 43:963-974.

Baker MA et al. 2008a. The rat sperm proteome characterized via IPG strip prefractionation and LC-MS/MS identification. Proteomics 8:2312-2321.

Baker MA et al. 2008b. The mouse sperm proteome characterized via IPG strip prefractionation and LCMS/MS identification. Proteomics 8:1720-1730.

Bansal AK, Bilaspuri GS. 2008. Oxidative stress alters membrane sulfhydryl status, lipid and phospholipid contents of crossbred cattle bull spermatozoa. Anim Reprod Sci 104:398-404.
Bartoov B et al. 1993. Estimating fertility potential via semen analysis data. Hum Reprod 8:65-70.

Beconi MT et al. 1991. Influence of antioxidants on SOD activity in bovine sperm. Biochem Int 23:545-553.

Brohmann $\mathrm{H}$ et al. 1997. Identification and characterization of new cDNAs encoding outer dense fiber proteins of rat sperm. J Biol Chem 272:10327-10332.

Cancel AM et al. 1997. Osteopontin is the 55-kilodalton fertility-associated protein in Holstein bull seminal plasma. Biol Reprod 57:1293-1301.

Cancel AM et al. 1999. Osteopontin localization in the Holstein bull reproductive tract. Biol Reprod 60:454460.

Cao W et al. 2006. Proteomic profiling of accessory structures from the mouse sperm flagellum. Mol Cell Proteomics 5:801-810.

Choi YJ et al. 2008. Cytochrome c upregulation during capacitation and spontaneous acrosome reaction determines the fate of pig sperm cells: linking proteome analysis. J Reprod Dev 54:68-83.

Cui Y et al. 2008. Proteomic analysis of testis biopsies in men treated with injectable testosterone undecanoate alone or in combination with oral levonorgestrel as potential male contraceptive. J Proteome Res 7:39843993.

D'Amours O et al. 2010. Proteomic comparison of detergentextracted sperm proteins from bulls with different fertility indexes. Reproduction 139:545-556.

D'Amours 0 et al. 2012. Epididymosomes transfer epididymal sperm binding protein 1 (ELSPBP1) to dead spermatozoa during epididymal transit in bovine. Biol Reprod 87:94.

Dada R et al. 2012. Epigenetics and its role in male infertility. J Assist Reprod Genet 29:213-223.

DeJarnette JM, Marshall CE. 2005. Straw-thawing method interacts with sire and extender to influence sperm motility and conception rates of dairy cows. J Dairy Sci 88:3868-3875.

Dogan S et al. 2015. Sperm protamine-status correlates to the fertility of breeding bulls. Biol Reprod 92:1-9.

Donkor FF et al. 2004. Outer dense fibre protein 2 (ODF2) is a self-interacting centrosomal protein with affinity for microtubules. J Cell Sci 117:4643-4651.

Feugang JM et al. 2009. Two-stage genome-wide association study identifies integrin beta 5 as having potential role in bull fertility. BMC Genomics 10:176.

Flickinger CJ et al. 2001. Outer dense fiber proteins are dominant postobstruction autoantigens in adult Lewis rats. Biol Reprod 64:1451-1459.

Fortes MR et al. 2014. Sperm protamine deficiency correlates with sperm DNA damage in $B$ os indicus bulls. Andrology 2:370-378.

Fujii J et al. 2003. Cooperative function of antioxidant and redox systems against oxidative stress in male reproductive tissues. Asian J Androl 5:231-242.

Fukuda Met al. 2016. Changes of IZUMO1 in bull spermatozoa during the maturation, acrosome reaction, and cryopreservation. Theriogenology 86:2179-2188.e3.

Harayama $\mathrm{H}$ et al. 2010. Relationship of protein tyrosine phosphorylation state with tolerance to frozen storage and the potential to undergo cyclic AMPdependent hyperactivation in the spermatozoa of Japanese Black bulls. Mol Reprod Dev 77:910-921.

Hoyer-Fender S et al. 1998. Mouse Odf2 cDNAs consist of evolutionary conserved as well as highly variable sequences and encode outer dense fiber proteins of the sperm tail. Mol Reprod Dev 51:167-175.

Hsieh YY et al. 2002. Superoxide dismutase activities of spermatozoa and seminal plasma are not correlated with male infertility. J Clin Lab Anal 16:127-131. 
Huber D et al. 2008. Molecular dissection of ODF2/Cenexin revealed a short stretch of amino acids necessary for targeting to the centrosome and the primary cilium. European J Cell Biol 87:137-146.

Kobayashi T et al. 1991. Protective role of superoxide dismutase in human sperm motility: superoxide dismutase activity and lipid peroxide in human seminal plasma and spermatozoa. Hum Reprod 6:987991.

Kutchy NA et al. 2017. Testis specific histone 2B is associated with sperm chromatin dynamics and bull fertility-a pilot study. Reprod Biol Endo 15:59. DOI:10.1186 s12958-017-0274-1

Kutchy NA et al. 2018. Acetylation and methylation of sperm histone 3 lysine 27 (H3K27ac and H3K27me3) are associated with bull fertility. Andrologia 50:10. DOI: $10.1111 /$ and.12915

Kwon WS et al. 2015a. Proteomic approaches for profiling negative fertility markers in inferior boar spermatozoa. Sci Rep 5:13821.

Kwon WS et al. 2015b. Discovery of predictive biomarkers for litter size in boar spermatozoa. Mol Cell Proteomics 14:1230-1240.

Kwon WS et al. 2015c. Increased male fertility using fertilityrelated biomarkers. Sci Rep 5:15654.

Lalancette C et al. 2006. Identification of the proteins present in the bull sperm cytosolic fraction enriched in tyrosine kinase activity: a proteomic approach. Proteomics 6:4523-4540.

Li LW et al. 2007. Establishment of a high-resolution 2-D reference map of human spermatozoal proteins from 12 fertile sperm-bank donors. Asian J Androl 9:321329.

Lindemann CB et al. 1988. An investigation of the effectiveness of certain antioxidants in preserving the motility of reactivated bull sperm models. Biol Reprod 38: 114-120.

Mariappa D et al. 2010. Inhibition of tyrosine phosphorylation of sperm flagellar proteins, outer dense fiber protein-2 and tektin-2, is associated with impaired motility during capacitation of hamster spermatozoa. Mol Reprod Dev 77:182-193.

Martinez-Heredia J et al. 2006. Proteomic identification of human sperm proteins. Proteomics 6:4356-4369.

Mruk DD et al. 2002. Antioxidant superoxide dismutase-a review: its function, regulation in the testis, and role in male fertility. Contraception 65:305-311.
Park YJ et al. 2012. Fertility-related proteomic profiling bull spermatozoa separated by percoll. J Proteome Res 11:4162-4168.

Park YJ et al. 2013. Proteomic revolution to improve tools for evaluating male fertility in animals. J Proteome Res 12:4738-4747.

Peddinti D et al. 2008. Comprehensive proteomic analysis of bovine spermatozoa of varying fertility rates and identification of biomarkers associated with fertility. BMC Syst Biol 2:19.

Peeker R et al. 1997. Superoxide dismutase isoenzymes in human seminal plasma and spermatozoa. Mol Hum Reprod 3:1061-1066.

Petersen C et al. 1999. Outer dense fibre proteins from human sperm tail: molecular cloning and expression analyses of two cDNA transcripts encoding proteins of $70 \mathrm{kDa}$. Mol Hum Reprod 5:627-635.

Rahman MS et al. 2017. Prediction of male fertility using capacitation-associated proteins in spermatozoa. Mol Reprod Dev 84:749-759.

Rizos D et al. 2003. Bovine embryo culture in the presence or absence of serum: implications for blastocyst development, cryotolerance, and messenger RNA expression. Biol Reprod 68:236-243.

SART Clinic Summary Report. [https://wwwsartcorsonlinecom/ rptCSR_PublicMultYearaspx?ClinicPKID=0]

Schalles U et al. 1998. Developmental expression of the 84-kDa ODF sperm protein: localization to both the cortex and medulla of outer dense fibers and to the connecting piece. Dev Biol 199:250-260.

Tarnasky H et al. 2010. Gene trap mutation of murine outer dense fiber protein-2 gene can result in sperm tail abnormalities in mice with high percentage chimaerism. BMC Dev Biol 10:67-... .

Thundathil JC et al. 2006. $\mathrm{Na}+/ \mathrm{K}+\mathrm{ATPa}$ e as a signaling molecule during bovine sperm capacitation. Biol Reprod 75:308-317.

van Gestel RA et al. 2007. Multiple proteins present in purified porcine sperm apical plasma membranes interact with the zona pellucida of the oocyte. Mol Hum Reprod 13:445-454.

Wang X et al. 2014. Tssk4 is essential for maintaining the structural integrity of sperm flagellum. Mol Hum Reprod 21:136-145.

Yoon SJ et al. 2016. Addition of cryoprotectant significantly alters the epididymal sperm proteome. PLoS One 11:e0152690. 